UNIVERSIDADE DA BEIRA INTERIOR

Ciências Sociais e Humanas

\title{
Mindfulness, Sexual Functioning and Subjective Sexual Well-Being
}

\author{
Vanessa Ricardo Martins \\ Dissertação para obtenção do Grau de Mestre em \\ Psicologia Clínica e da Saúde \\ ( $2^{\circ}$ ciclo de estudos)
}

Orientador: Prof. Doutor Henrique Pereira

Covilhã, Junho de 2015 


\section{Agradecimentos}

Ao Professor Doutor Henrique Pereira, meu orientador, a quem dirijo uma palavra de apreço e sincero agradecimento pela disponibilidade, dedicação, paciência e apoio que se mostraram essenciais na realização deste trabalho. 0 meu sincero obrigado, por todas as horas dispendidas, pela crucial ajuda na análise estatística e ainda por todas as palavras de encorajamento que me dirigiu.

Ao Departamento de Psicologia e Educação da Universidade da Beira Interior, em especial à equipa de investigação da qual fiz parte, composta por professores e alunos, que me acompanharam ao longo desta jornada.

À imensa família, em especial aos meus pais, que sempre me deram imenso apoio, incentivo e, sem eles, esta etapa da minha vida não teria sido possível. 0 meu imenso obrigado por terem sido o meu porto seguro e pelo seu amor incondicional.

Ao Carlos, pelo seu apoio absoluto, pela imensa paciência, respeito, compreensão, ternura e cumplicidade, principalmente nos momentos em que eu mais precisava. 0 meu sincero agradecimento por me fazer sorrir e nunca me ter deixado desistir.

A todos os amigos, aos verdadeiros e sempre presentes, pelo carinho, apoio, boa disposição e, essencialmente, pela amizade, o meu muito obrigada. 


\section{Resumo}

No âmbito do mestrado em Psicologia Clínica e da Saúde apresenta-se a presente dissertação, que está organizada em formato de artigo, que, tal previsto no regulamento do grau de mestre em Psicologia da Universidade da Beira Interior, prevê a inclusão de artigo(s) já submetido(s) a publicação, atendendo à normas específicas da publicação científica em causa (neste caso também em língua inglesa). Assim, este documento descreve a pesquisa realizada no ano letivo de 2014/2015 na Unidade Curricular de Dissertação, com a finalidade de desenvolver procedimentos metodológicos que permitiram compreender as relações entre Mindfulness, Funcionamento sexual e bem-estar sexual subjetivo. Mais especificamente, os objetivos foram os seguintes: (1) Avaliação dos níveis de mindfulness, funcionamento sexual e bem-estar sexual subjetivo numa amostra de adultos de expressão portuguesa; (2) Comparação das diferenças dos níveis de mindfulness, funcionamento sexual e bem-estar sexual subjetivo entre géneros (masculino e feminino) e entre as diferentes faixas etárias e (3) Determinação de uma relação preditiva entre mindfulness, funcionamento sexual e bem-estar sexual subjetivo.

É ainda de referir que se apresenta também a submissão ao Journal of Mindfulness, assim como um anexo comprovativo da mesma. Na parte final da presente dissertação é apresentado o anexo teórico, o qual foi elaborado enquanto a recolha de dados estava a ser elaborada. Assim, este pretende ser uma base teórica sólida para uma melhor compreensão dos construtos presentes no estudo - Mindfulness, funcionamento sexual e bem-estar sexual subjetivo - abordando algumas questões cruciais acerca destes.

\section{Palavras-chave}

Mindfulness; Mudanças no Funcionamento Sexual; Bem-estar Sexual Subjetivo; Género; Faixas etárias; Portugal; 


\section{Abstract}

This dissertation is presented under the Masters' program in Clinical and Health Psychology and is organized in the scientific paper format, which, according to the regulation of the master's degree in Psychology from the University of Beira Interior, allows the inclusion of scientific papers already submitted for publication, given the specific instructions of scientific publication (in this case also in English). Thus, this document describes the research conducted in the academic year of 2014/2015 in the Dissertation Course, to develop methodological procedures that allowed us to understand the relationship between Mindfulness, sexual functioning and subjective sexual wellbeing. More specifically, the objectives were: (1) to assess levels of mindfulness, sexual functioning and subjective sexual well-being in a Portuguese-speaking adult sample; (2) to compare differences on the levels of mindfulness, sexual performance and subjective sexual well-being between genders (male and female) and among different age groups and (3) to determination of a predictive relationship between mindfulness, sexual functioning and Subjective sexual well-being.

It should also be noted that there is a submission to the Journal of Mindfulness, as well as a submission proof Annex in this dissertation. In the final part, a theoretical Annex is included, which was prepared while data were being collected. This is intended to be a solid theoretical basis for a better understanding of the constructs present in the study - Mindfulness, sexual functioning and subjective sexual well-being - addressing some crucial questions about these.

\section{Keywords}

Mindfulness; Changes in sexual functioning; Subjective sexual well-being; Gender; Age groups; Portugal 


\section{Índice}

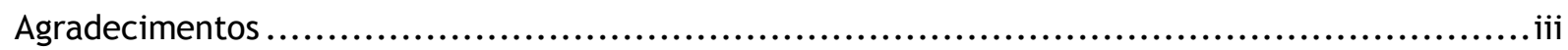

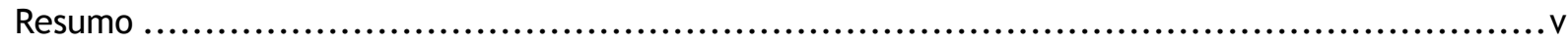

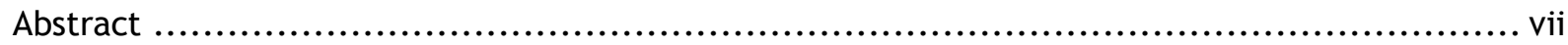

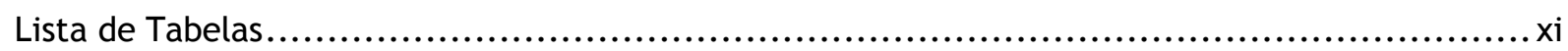

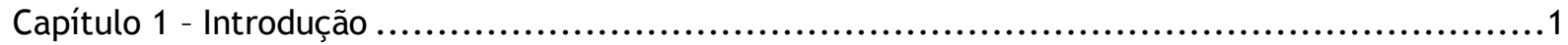

Capítulo 2 - Mindfulness, Sexual Functioning and Subjective Sexual Well-Being .......................2

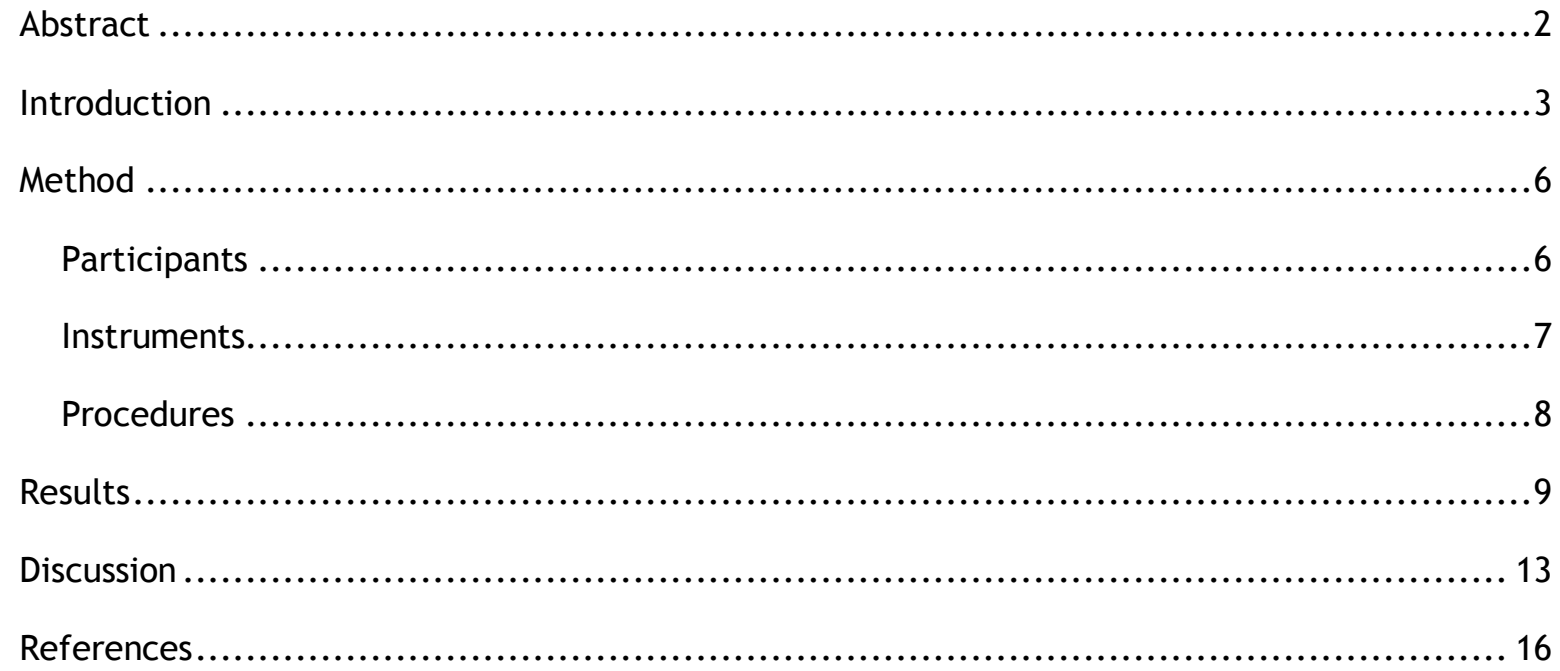

Capítulo 3 - Discussão Geral ................................................................. 23

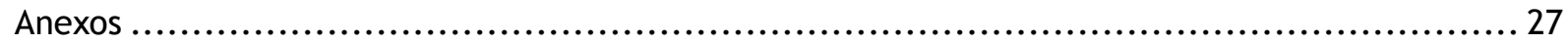

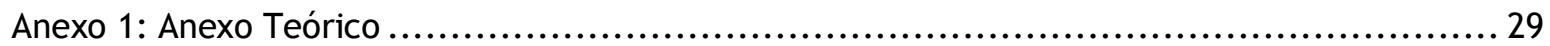

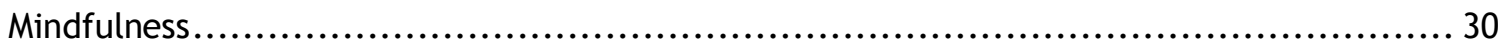

Mudanças no funcionamento sexual ....................................................42

Bem-estar sexual subjetivo........................................................... 52

Mindfulness, mudanças no funcionamento sexual e bem-estar sexual subjetivo............... 54

Referências Bibliográficas ................................................................61

Anexo 2: Comprovativo da submissão à revista do artigo científico $\ldots \ldots \ldots \ldots \ldots \ldots \ldots \ldots \ldots \ldots \ldots \ldots . . . \ldots 5$ 


\section{Lista de Tabelas}

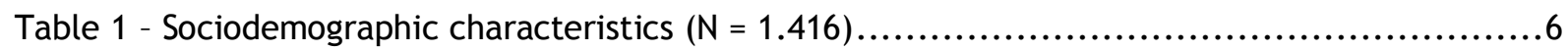

Table 2 - Results of gender differences in sexual functioning, subjective sexual well-being, and

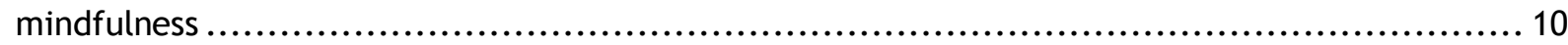

Table 3 - Results of different age groups in mindfulness, sexual functioning, and subjective sexual

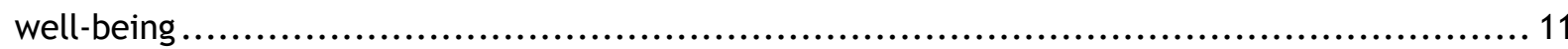

Table 4 - Results of the differences between levels of mindfulness and sexual functioning and subjective sexual well-being 


\section{Capítulo 1 - Introdução}

No âmbito do mestrado em Psicologia Clínica e da Saúde apresenta-se a presente dissertação, cujos objetivos passam por: (1) Avaliar os níveis de mindfulness, de funcionamento sexual e de bem-estar sexual subjetivo numa amostra de adultos de expressão portuguesa; (2) Comparar as diferenças nos níveis de mindfulness, de funcionamento sexual e bem-estar sexual subjetivo entre géneros (masculino e feminino) e entre diferentes faixas etárias e (3) Determinar uma relação preditiva entre mindfulness, funcionamento sexual e bem-estar sexual subjetivo.

Com o passar do tempo, vários estudos foram elaborados acerca das três variáveis supracitas e têm sido feitos esforços frenéticos no sentido de se conhecer um pouco melhor o funcionamento global do ser humano, nomeadamente no que concerne à sua função sexual. Assim, apesar de haver um considerável número de estudos acerca de mindfulness, funcionamento sexual e bem-estar sexual subjetivo, poucos são aqueles que tentam relacionar estas três áreas. Neste sentido, a presente dissertação, pretende ser um contributo na área científica, de modo a que possa ser melhor entendida a associação existente entre mindfulness, funcionamento sexual e bem-estar sexual subjetivo.

Uma vez que poucos são os estudos que exploram quais as associações entre os três construtos referidos, o presente trabalho pretende ser um contributo do ponto de vista da Psicologia, uma vez que existem evidências na literatura e que vão de encontro com os resultados aqui obtidos que indicam que elevados níveis de mindfulness levam, consequentemente, a uma melhor funcionamento sexual e bem-estar sexual subjetivo.

Neste seguimento, numa primeira parte irá ser apresentado o artigo científico submetido para publicação onde irá constar uma breve introdução acerca do tema em apreço, uma descrição dos métodos utilizados no presente estudo, quais os resultados obtidos e a discussão dos mesmos. Seguidamente irá ser apresentada uma discussão geral onde irão ser abordados vários domínios, nomeadamente uma reflexão acerca dos resultados e aplicação à Psicologia e também uma breve reflexão sobre o término do $2^{\circ}$ ciclo em Psicologia Clínica e da Saúde. Por fim, numa última parte, irá ser apresentado o anexo teórico onde todas as variáveis do presente estudo irão ser abordadas de uma forma mais concreta, para uma melhor compreensão acerca do mindfulness, do funcionamento sexual e do bem-estar sexual subjetivo. 


\section{Capítulo 2 - Mindfulness, Sexual Functioning and Subjective Sexual Well- Being}

This chapter is based on the paper:

Martins, V., Pereira, H., Esgalhado, G., Afonso, R. M., Monteiro, S. \& Loureiro, M. (Submitted). Mindfulness, Sexual Functioning, and Subjective Sexual Well-Being. Journal of Mindfulness

\section{Abstract}

Although there are several studies that address mindfulness, sexual functioning, and subjective sexual well-being separately, there are very few studies that explore the associations between these three constructs. Therefore, this research was developed with the objective of evaluating levels of mindfulness, sexual functioning, and sexual well-being in a Portuguese-speaking adult sample in order to compare the differences in these measures between genders (male and female) and age groups, and to determine a predictive relationship between mindfulness, sexual functioning, and subjective sexual well-being. The sample consists of 1.416 Portuguese-speaking adults, with a mean age of 38.74 years of age $(S D=13.63)$. Participants completed the "The Freiburg Mindfulness Inventory - reduced version (IMF)", the Changes in Sexual Functioning Questionnaire-Short Form (CSFQ-14), and the "Subjective sexual well-being" questionnaire. After analyzing the levels of mindfulness, sexual performance, and subjective sexual well-being, we found that the participants had moderately high indicators for all variables. In regards to the comparison between genders, it was found that men have higher levels of mindfulness and sexual functioning than women. Regarding subjective sexual well-being, men also show higher values in almost all variables. It was also found that participants between 30 and 49 years of age demonstrated, in general, higher levels of mindfulness, sexual functioning, and subjective sexual well-being. Linear regression shows that having higher levels of mindfulness is a good predictor of enjoying more sexual pleasure and experiencing orgasm, demonstrating that mindfulness seems to condition sexual experiences. This study draws attention to the importance of further examining the selected variables, in order to provide relevant information to technicians who work in this field. 


\section{Keywords}

Mindfulness; Changes in sexual functioning; Subjective sexual well-being; Gender; Age groups; Portugal

\section{Introduction}

Mindfulness is the translation of the term "Sati" in Pali, which means remember, recognize, and be intentionally aware. It also implies that one must possess a vigilant and lucid mind, be alert, and self-conscious (Sillifant, 2007; Siegel, Germer \& Olendzki, 2009; Simon, 2011). Historically, mindfulness was defined as the "heart" of Buddhist meditation (Thera, 1962) and lay at the core of the Buddha's teachings (Gunaratana, 1992; Hanh, 1999; Nanamoli \& Bodhi, 1995; Hanh, 1976; KabatZinn , 2003). Over time, following increased investigation of mindfulness (Edwards, Bryning \& Crane, 2014; Edwards \& Bryning, 2013; Kabat-Zinn, 2013), the meaning of the word has since evolved (Simón, 2011).

The concept mindfulness appears to be simple however, its description and characterization has no consensus among researchers (Bishop et al., 2004; Neves, 2011). It's hard to build consensus when it comes to clarifying and distinguishing the essential components of mindfulness, as well as the psychological processes involved, and their respective outcomes (Bishop et al., 2004; Sillifant, 2007; Hayes \& Wilson, 2003).

According to the Buddhist perspective, mindfulness embraces a range of cognitive, ethical, and emotional dimensions (Grossman, 2010). In this sense, the most widely accepted definition of mindfulness is a type of awareness and knowledge that results from paying deliberate attention to the present moment, without making any value judgments about the experience itself, and while allowing the mind to focus with increased awareness, self-awareness, and the reduction of automatic thoughts (Brefczynski-Lewis, Lutz Schaefer, Levinson \& Davidson, 2007; Brown \& Ryan, 2003; Shapiro \& Schwartz 2005; Holas \& Jankowski, 2013).

Therefore, mindfulness-based therapy is founded on the assumption that paying attention to control skills can help individuals change their relationship with the usual pattern of dysfunctional automatic thoughts (Fernandes, 2010), and, in this sense, place more emphasis on this dynamic and on the process itself (Fernandes, 2010; Hayes \& Gregg, 2002). 
Over time, indications have emerged that attention levels can be a predictor of various outcomes, such as health, well-being, adaptive qualities, cognitive flexibility, emotional intelligence, and life satisfaction ( Anderson, Lau, \& Bishop Segal, 2007; Brown \& Kasser, 2005; Christopher, Charoensuk Gilbert, Neary \& Pearce, 2009; Weinstein, Brown \& Ryan, 2009). In addition to the aforementioned qualities, the evidence shows significant associations between mindfulness and increased coping, functional abilities in cognition, affections, performance and behavior (Fernandes, 2010; Neves, 2011), and welfare and health (Lazaridou \& Kalogianni, 2013). Significant associations are also seen between mindfulness and the control of negative affections in the warning capacity and sustained attention (Carmody, 2009), performance improvement (Chambres, Yee-Lo \& Allen, 2008; Jha, Krompinger \& Baime, 2007; Tang et al, 2007), memory (Brotto, 2013), a decrease in emotional reactivity in managing emotions (Franco, Manas \& Just, 2009), and sexuality (McCarthy \& Wald, 2013; Lazaridou \& Kalogianni, 2013; Brotto \& Heiman, 2007; Justo, Manas \& Martínez, 2010; Coffey \& Hartman, 2008).

Particularly in relation to sexuality, mindfulness seems to positively contribute to a significant improvement in sexual functioning and subjective sexual well-being, since being sexually selfconscious is known to have positive effects on sexual performance. Hence, the self interferes positively with excitement and with the process of pleasure, thus improving sensitivity and awareness and adopting an attitude of openness and acceptance, which, in turn, seems to promote the expression of sexuality (McCarthy \& Wald, 2013; Goldmeier, 2013). In this sense, mindfulness tries to maintain focus on the mind and body, as well as everything that is occurring. Therefore, this practice seems to offer a unique approach to improving issues related to sexuality (Brotto, Krychman \& Jacobson, 2008).

One of the basic premises of mindfulness in the area of sexuality is the acceptance of physical and psychological relaxation, based on sexual response (McCarthy \& Wald, 2013). Consequently, the focus of attention is not on the individual's sexual performance, but on sexual desire, framing sexual satisfaction as an interpersonal process (McCarthy \& Wald, 2013). The mindfulness component emphasizes the awareness and acceptance of the level of involvement and response, rather than forcing a sexual response or avoiding the pleasurable processes involved in sexual activity. Strategies and mindfulness techniques invite the individual to accept and adopt a new set of physical and psychological abilities, assuming full control and responsibility for their sexual wellbeing (McCarthy \& Wald, 2013).

The mindfulness associated with sexuality is used in order to increase desire, pleasure, eroticism, and sexual satisfaction in a couple or in an individual. Given that the main components of healthy sexuality are sexual desire and satisfaction, mindfulness tends to enhance these components (McCarthy \& Wald, 2013; Lucena \& Abdo, 2013). The practice of mindfulness leads to an increased ability to understand the perspective of a partner (Carson, Carson, Gil \& Baucom, 2004; Brotto \& 
Heiman, 2007; Burpee \& Langer, 2005), that is, to be aware of the partner's opinion, which is linked to significantly increased marital satisfaction, thus improving sexual performance and subjective sexual well-being (Lazaridou \& Kalogianni, 2013; McCreary \& Alderson, 2013).

The sexual response cycle can be influenced negatively by various psychological factors, including anxiety, low self-esteem, disturbances in perception of body image, fear of rejection, sexual performance anxiety, traumatic sexual experiences, history of abuse, and even the quality of relationships (Mendonça, Silva, Arrudai, Garcia-Zapata \& Amaral, 2012). In this sense, mindfulness appears as a protective factor and facilitator of a positive sexual experience, in that it promotes cognitive, behavioral, and emotional awareness, in addition to an attitude of acceptance and a focus on immediate sexual sensations (McCarthy \& Wald, 2013). Therefore, the association of mindfulness with sexuality allows for significant advantages for humans, because mindfulness leads to the acquisition of important skills for sexual function, namely, the effective management of time, energy, courage, determination, and discipline (Goldmeier, 2013).

Sexuality is an integral part of human life and it promotes intimacy, connection, and pleasure (Diamond \& Huebner, 2012; Buckstegge, Gouveia, Mafra \& Bobato, 2009; Lerner, 2012; McCarthy \& Wald, 2013). It turns out that sexuality is responsible for a set of personal and social needs, hence sexual health and well-being are linked inseparably to physical and mental health (Frohlich \& Meston, 2002). Sexuality is also connected to the operation of sexual mechanisms, which are based on patterns of sexual response for men and women (desire, arousal, orgasm, and resolution) (Lucena \& Abdo, 2013), and which are also important variables in the self-assessment of relationship satisfaction and overall well-being (Buckstegge, Gouveia, Mafra \& Bobato, 2009). As a result, it is understood that sexual problems can be a source of suffering and dissatisfaction (Mendonça, Silva, Arrudai, Garcia-Zapata \& Amaral, 2012). Subjective sexual well-being refers to the perception of the quality of one's sexuality and sexual life (Edwards \& Bryning, 2013). Studies on sexual well-being, examined sexual satisfaction in several areas, including satisfaction with the physical and emotional aspects of relationships, satisfaction with sexual functioning, and the importance of sexuality in life in general (Laumann, Paik \& Rosen, 1999). Based upon this research, the concept of subjective sexual well-being is defined as a cognitive and emotional evaluation of the sexuality of a subject (Traeen \& Schaller, 2010; Oberg, Fugl-Meyer \& Fugl-Meyer, 2002), which results from the subject's perceptions concerning his/her emotional and physical satisfaction in several areas of sexuality and health. Subjective sexual well-being is particularly useful because it is a much more encompassing term than sexual satisfaction (Traeen \& Schaller, 2010).

Despite that fact that there are many studies that separately address mindfulness, sexual functioning, and subjective sexual well-being, there are very few that explore which associations can be made between these three constructs. In order to fill this gap in the research we developed this study with the following objectives: to evaluate levels of mindfulness, sexual functioning, and 
subjective sexual well-being in a sample of Portuguese-speaking adults; to compare the differences in the levels of mindfulness, sexual functioning, and subjective sexual well-being between genders (male and female), as well as among different age groups; and to determine a predictive relationship between mindfulness, sexual functioning, and subjective sexual well-being.

\section{Method}

\section{Participants}

The study's sample consists of 1,416 Portuguese-speaking adults, of whom 604 (42.70\%) are male and $812(57.30 \%)$ are female. Regarding marital status, $490(33.40 \%)$ are single, $548(38.10 \%)$ are married, $129(10 \%)$ are in civil union, $16(1.10 \%)$ are widowed, $129(10 \%)$ are in an emotionally committed relationship, and 104 (7.40\%) report a different marital status. It should also be noted that most of the participants possess a university education. With regard to sexual orientation, $1.320(93.40 \%)$ participants self-identity as heterosexual, $27(1.90 \%)$ as bisexual, and $69(4.70 \%)$ as homosexual. In regards to having children, 649 (45.80\%) participants said that they have children and 767 (54.20\%) are childless. Regarding the participants' place of residence, 164 (11.60\%) subjects live in rural areas and $1.252(88.40 \%)$ live in urban areas. Concerning employment status $82(6.2 \%)$ participants are unemployed, $202(15.30 \%)$ are students, 1,061 (72.30\%) are employed, $56(4.60 \%)$ are retired, and $15(1.60 \%)$ report being in a different employment situation. The entirety of the previously mentioned data is analyzed in Table 1. Regarding age, the mean age is 38.74 ( $S D=13.63$ ) years old.

Table 1 - Sociodemographic characteristics $(\mathrm{N}=1.416)$

\begin{tabular}{lcc}
\hline & $\mathrm{N}$ & $\%$ \\
\hline Gender & & 42.70 \\
Male & 604 & 57.30 \\
Female & 812 & 33.40 \\
Marital status & & 38.10 \\
Single & 490 & 10.00 \\
Married & 548 & 1.10 \\
Civil union & 129 & 10.00 \\
Widowed & 16 & 7.40 \\
Emotional commitment & 129 & \\
Other & 104 & 0.20 \\
Education & & 0.50 \\
Up to 4 years & 1 & 2.20 \\
Up to 6 years & 4 & 12.90 \\
Up to 9 years & 30 & 0.37 \\
Up to 12 years & 185 & 32.80 \\
University training & 3 & 37.40 \\
Undergraduate & 464 & \\
Postgraduate & 535 & \\
\hline
\end{tabular}




\begin{tabular}{ccc}
\hline Ph.D. & 191 & 13.63 \\
Sexual orientation & 1320 & 93.40 \\
Heterosexual & 27 & 1.90 \\
Bisexual & 69 & 4.70 \\
Homosexual & & \\
Children & 767 & 54.20 \\
No & 649 & 45.80 \\
Yes & & \\
Place of residence & 164 & 11.60 \\
Rural area & 1252 & 88.40 \\
Urban area & & \\
Professional status & 82 & 6.20 \\
Unemployed & 202 & 15.30 \\
Student & 1061 & 72.30 \\
Employed & 56 & 4.60 \\
Retired & 15 & 1.60 \\
Other & & \\
\hline
\end{tabular}

\section{Instruments}

In order to compile information about the participants in the survey, we put together a sociodemographic questionnaire, which included items such as age, gender, current place of residence, level of education, marital status, sexual orientation, whether participants have children or not, and employment status.

With the aim of assessing the mindfulness experience of the participants, we used the "The Freiburg Mindfulness Inventory - short version (FMI)" (Walach, Buchheld, Buttenmuller, Kleinknecht \& Schmidt, 2006). The FMI - short version reduces the original survey from 30 to 14 items, and the Portuguese version has a Cronbach's alpha of 0.86 , indicating good internal consistency levels (Maroco \& Garcia-Marques, 2006).

The FMI is a consistent and reliable scale and takes into account important aspects of mindfulness (Walach, Buchheld, Buttenmuller, Kleinknecht \& Schmidt, 2006). In addition, the validation study demonstrates that the FMI is a useful, valid, and reliable questionnaire, when used to measure levels of full attention (Walach, Buchheld, Buttenmuller, Kleinknecht \& Schmidt, 2006). The reduced scale of 14 items also includes all aspects of mindfulness in the context of Buddhist meditation, and correlates almost perfectly with the full scale (Walach, Buchheld, Buttenmuller, Kleinknecht \& Schmidt, 2006).

To assess changes in sexual functioning, we used the Changes in Sexual Functioning QuestionnaireShort Form (CSFQ-14) (Keller, McGarvey \& Clayton, 2006). This questionnaire is a clinical and research instrument, which initially consisted of 36 items concerning the five scales of sexual functioning (Keller, McGarvey \& Clayton, 2006). Later, a smaller version of the instrument with 14 items was created, which evaluates the three dimensions that correspond to the phases of the 
sexual response cycle (desire, arousal, and orgasm), as well as the five factors of the original questionnaire (Keller, McGarvey \& Clayton, 2006). Factor analysis confirms the validity of this construct as a global measure of sexual dysfunction (Keller, McGarvey \& Clayton, 2006). It should also be noted that the individual scales exhibit a strong level of internal reliability with a Cronbach's alpha of 0.90 (Keller, McGarvey \& Clayton, 2006). The level of significance of this study is 0.85 , which indicates high levels of internal consistency (Maroco \& Garcia-Marques 2006). After analyzing the questionnaire, in accordance with the proposal of the author, the questionnaire was organized into five different dimensions: desire and frequency of sexual activity, desire and interest, arousal, pleasure, and orgasm (Keller, McGarvey \& Clayton, 2006). Finally, a global scale was developed from the 14 items of sexual functioning.

Subjective sexual well-being was assessed according to Laumann et al.'s (2006) proposal and consists of four items. The first item evaluates the "level of satisfaction with the physical pleasure felt in relation to your partner in the last 12 months." The second investigates the "level of satisfaction with the emotional pleasure felt in relation to your partner in the last 12 months." The third item asks participants, "If you had to spend the rest of your life with the sexual life that you have today (sexual relationships and sexual health), how would you feel?" Finally, the fourth item addresses "the importance that sex has on your overall life". The responses are scored in a Likerttype scale where responses for items 1, 2, and 3 vary between "completely unsatisfied", "moderately dissatisfied", "neither dissatisfied, nor satisfied", "moderately satisfied", and "extremely satisfied". The possible responses for item 4 are "not important at all", "not very important", "somewhat important", "very important", and "extremely important." The original alpha was 0.80 , consistent with the value obtained in the present study (also 0.80 ), representing a very good level of internal consistency (Maroco \& Garcia-Marques, 2006).

\section{Procedures}

Participants were recruited online and were invited to fill out the survey, which was conducted between October 2014 and February 2015. A specific link for the purposes of this investigation was put together, and was disseminated through mailing lists, contacts with organizations, and social networks.

The online page presented the goals of the study and included all of the principles of traditional psychological research ethics, namely the perseveration of confidentiality and anonymity, as well as informed consent, which were met. 
Recruitment focused on obtaining a normative sample of the Portuguese population. Direct requests for voluntary participation were sent out, explaining the study's objectives, along with instructions and the contact information of the research team.

The Scientific Committee of the Department of Psychology and Education at the University of Beira Interior approved this study. The study also complies with all ethical principles set by the Portuguese Board of Psychologists for research development as well as the guidelines of the American Psychological Association regarding conducting studies involving human beings.

\section{Results}

Regarding mindfulness levels, the predicted median was 34 points, and the observed mean was 40.39 , with a standard deviation of 6.95 . Thus, we can infer that participants have moderately high indicators of mindfulness levels.

When assessing the levels of sexual functioning among our sample, it is found that the participants have moderately high indicators in the various areas studied. When considering the "pleasure" scale, the expected median was 3.4 and the observed mean was 3.45 ( $S D=1.13$ ). In regards to the "desire and sexual frequency" dimension, the expected median was 6 and the observed mean was $6.69(S D=1.69)$. For the "desire and interest" scale, the expected median was 9 and the observed mean was 9.32 ( $\mathrm{sd}=2.63$ ). The "Arousal" scale had an expected median of 9 and an observed mean of 2.11 (SD = 2.46). The "Orgasm" scale showed an expected median of 9 and an observed mean of 11.77 (sd = 2.62). Finally, in regards to overall sexual functioning, the expected average was 42.00 and the observed mean was $45.63(\mathrm{sd}=8.19)$.

When analyzing subjective sexual well-being, we found that the subjects had moderately high indicators for the various domains. For the level of satisfaction with physical pleasure, the expected median was 3 and the observed mean was 4.04 ( $s d=1.9$ ). Regarding the level of emotional pleasure, the expected median was 2.5 and the observed mean was 3.41 (sd =1.78). Concerning how participants would they feel if they had to spend the rest of their life with their current sex life, the expected median was 2.5 and the observed mean was 3.17 ( $\mathrm{sd}=1.81$ ). Finally, regarding the importance that sex has on participants' overall life, the expected median was 2.5, with an observed mean of $3.09(\mathrm{sd}=1.57)$ for this parameter.

In order to compare the differences in the levels of mindfulness, sexual functioning, and subjective sexual well-being between genders and among different age groups, we conducted Student's t-tests on the independent samples, in addition to one-way ANOVAs. 
Concerning the comparison between males and females, we found the following statistically significant differences. With respect to mindfulness, men score higher than women. When it comes to sexual functioning, male participants indicate higher values in all parameters, which signifies that men report higher levels of pleasure, desire, frequency of desire and interest, arousal, and orgasm. Regarding overall sexual functioning, men also have higher values when compared with women. Finally, with respect to variables related to subjective sexual well-being, men also possess higher values in most variables. Men had greater satisfaction with emotional pleasure, concerning the idea of having to spend the rest of their lives with their current sex life, and in regards to the importance they attach to sex in their overall life. In turn, women had higher levels of satisfaction in regards to physical pleasure. All of these results are shown in Table 2.

Table 2 - Results of gender differences in sexual functioning, subjective sexual well-being, and mindfulness

\begin{tabular}{cccccc}
\hline & Gender & Mean & $\begin{array}{c}\text { Standard } \\
\text { Deviation (SD) }\end{array}$ & $\mathrm{t}$ (df) & $\begin{array}{c}p- \\
\text { value }\end{array}$ \\
\hline Pleasure & Male & 3.62 & 0.98 & $\mathrm{t}(1401)=5.09$ & $0.000^{* *}$ \\
& Female & 3.31 & 1.21 & & \\
Desire and frequency & Male & 7.45 & 1.41 & $\mathrm{t}(1395)=15.63$ & $0.013^{*}$ \\
& Female & 6.13 & 1.67 & & \\
Desire and interest & Male & 10.65 & 2.27 & $\mathrm{t}(1380)=18.09$ & 0.272 \\
& Female & 8.33 & 2.43 & & \\
Arousal & Male & 12.21 & 2.03 & $\mathrm{t}(1248)=14.31$ & $0.000^{* *}$ \\
& Female & 10.31 & 2.42 & & \\
Orgasm & Male & 13.04 & 1.89 & $\mathrm{t}(1252)=14.49$ & $0.000^{* *}$ \\
& Female & 10.99 & 2.69 & & \\
Overall sexual functioning & Male & 50.08 & 6.49 & $\mathrm{t}(1173)=16.17$ & $0.000^{* *}$ \\
& Female & 42.89 & 7.92 & & \\
Satisfaction with physical & Male & 4.03 & 1.08 & $\mathrm{t}(1189)=-0.43$ & 0.452 \\
pleasure & Female & 4.05 & 1.08 & & \\
Satisfaction with emotional & Male & 3.64 & 1.59 & $\mathrm{t}(1410)=4.26$ & $0.000^{* *}$ \\
pleasure & Female & 3.24 & 1.89 & & \\
Spending the rest of their & Male & 3.38 & 1.68 & $\mathrm{t}(1410)=3.77$ & $0.000^{* *}$ \\
life with their current sex & Female & 3.01 & 1.89 & & \\
life & Male & 3.48 & 1.45 & $\mathrm{t}(1410)=8.06$ & $0.000^{* *}$ \\
Importance of sex in the & Female & 2.81 & 1.59 & & \\
overall life & Male & 41.06 & 6.84 & $\mathrm{t}(1335)=3.07$ & 0.262 \\
Overall mindfulness & Female & 39.89 & 6.99 & & \\
& & & & &
\end{tabular}


In order to compare differences in the levels of mindfulness, changes in sexual functioning, and subjective sexual well-being among age levels, we divided the sample into three different age groups (14-29, 30-49, and over 50). This division was made in order to accommodate and respect developmental criteria (Papalia, Olds \& Feldman, 2008). As can be seen in Table 3, statistically significant differences were found for all sexual dimensions studied, except for "satisfaction with physical pleasure". This indicates that the group of participants between ages 30 and 49 present higher scores than in the other age groups. Regarding "mindfulness", the group of participants older than 50 years old presented higher scores (see Table 3 ).

Table 3 - Results of different age groups in mindfulness, sexual functioning, and subjective sexual well-being

\begin{tabular}{|c|c|c|c|c|c|}
\hline & Age groups & Mean & $\begin{array}{l}\text { Standard } \\
\text { Deviation }\end{array}$ & $\mathrm{Z}(\mathrm{df})$ & $p$-value \\
\hline \multirow{4}{*}{ Pleasure } & $14-29$ & 3.48 & 1.19 & & \\
\hline & $30-49$ & 3.48 & 1.07 & $z(2 ; 1370)=3.13$ & $0.044^{*}$ \\
\hline & $>50$ & 3.30 & 1.13 & & \\
\hline & $14-29$ & 6.60 & 1.68 & & \\
\hline \multirow[t]{3}{*}{ Desire and frequency } & $30-49$ & 6.93 & 1.64 & $z(2 ; 1365)=12.96$ & $0.000^{* *}$ \\
\hline & $>50$ & 6.36 & 1.77 & & \\
\hline & $14-29$ & 9.26 & 2.51 & & \\
\hline \multirow[t]{3}{*}{ Desire and interest } & $30-49$ & 9.66 & 2.65 & $z(2 ; 1350)=27.38$ & $0.000^{* *}$ \\
\hline & $>50$ & 8.79 & 2.60 & & \\
\hline & $14-29$ & 10.98 & 2.38 & & \\
\hline \multirow[t]{3}{*}{ Arousal } & $30-49$ & 11.49 & 2.25 & $z(2 ; 1222)=27.38$ & $0.000^{* *}$ \\
\hline & $>50$ & 10.19 & 2.71 & & \\
\hline & $14-29$ & 11.37 & 2.77 & & \\
\hline \multirow[t]{3}{*}{ Orgasm } & $30-49$ & 12.10 & 2.37 & $z(2 ; 1225)=9.19$ & $0.000^{* *}$ \\
\hline & $>50$ & 11.69 & 2.79 & & \\
\hline & $14-29$ & 45.42 & 8.11 & & \\
\hline \multirow[t]{2}{*}{ Overall sexual functioning } & $30-49$ & 46.82 & 7.78 & $z(2 ; 1148)=13.74$ & $0.000^{* *}$ \\
\hline & $>50$ & 43.57 & 8.76 & & \\
\hline \multirow{3}{*}{$\begin{array}{l}\text { Satisfaction with physical } \\
\text { pleasure }\end{array}$} & $14-29$ & 4.12 & 1.04 & & \\
\hline & $30-49$ & 4.12 & 1.07 & $z(2 ; 1161)=1.99$ & 0.136 \\
\hline & $>50$ & 3.94 & 1.18 & & \\
\hline \multirow{3}{*}{$\begin{array}{l}\text { Satisfaction with emotional } \\
\text { pleasure }\end{array}$} & $14-29$ & 3.26 & 1.92 & & \\
\hline & $30-49$ & 3.53 & 1.64 & $z(2 ; 1379)=3.03$ & $0.048^{*}$ \\
\hline & $>50$ & 3.37 & 1.83 & & \\
\hline Spending the rest of their & $14-29$ & 2.96 & 1.89 & & \\
\hline life with their current sex & $30-49$ & 3.30 & 1.70 & $z(2 ; 1379)=4.54$ & $0.011^{*}$ \\
\hline \multirow{5}{*}{$\begin{array}{l}\text { Importance of sex in the } \\
\text { overall life }\end{array}$} & $>50$ & 3.12 & 1.87 & & \\
\hline & $14-29$ & 2.82 & 1.66 & & \\
\hline & $30-49$ & 3.28 & 1.44 & $z(2 ; 1379)=11.14$ & $0.000^{* *}$ \\
\hline & $>50$ & 3.12 & 1.62 & & \\
\hline & $14-29$ & 39.16 & 6.95 & & \\
\hline \multirow[t]{2}{*}{ Overall mindfulness } & $30-49$ & 40.19 & 7.22 & $z(2 ; 1304)=18.25$ & $0.000^{* *}$ \\
\hline & $>50$ & 42.23 & 6.13 & & \\
\hline
\end{tabular}


In order to compare differences in sexual functioning and subjective sexual well-being between groups with higher and lower levels of mindfulness, with the goal of inferring the influence of mindfulness on sexual variables, we utilize the observed median as the cut-off point. The first group refers to lower levels of mindfulness $(<41)$ and the second group refers to higher levels of mindfulness (>41). All variables in this study were analyzed independently using this criterion. The results show a statistically significant difference between high and low levels of mindfulness in regards to pleasure and orgasm. For all other variables of sexual functioning and subjective sexual well-being there were no statistically significant differences, as can be seen in Table 4 .

Table 4 - Results of the differences between levels of mindfulness and sexual functioning and subjective sexual well-being

\begin{tabular}{|c|c|c|c|c|c|}
\hline & $\begin{array}{l}\text { Mindfulness } \\
\text { levels }\end{array}$ & Mean & $\begin{array}{l}\text { Standard } \\
\text { Deviation }\end{array}$ & $t(d f)$ & $P$ \\
\hline \multirow{2}{*}{ Pleasure } & Lower levels & 3.23 & 1.14 & \multirow{2}{*}{$t(1330)=-8.02$} & \multirow{2}{*}{$0.009^{*}$} \\
\hline & Higher levels & 3.71 & 1.06 & & \\
\hline \multirow{2}{*}{ Desire and frequency } & Lower levels & 6.40 & 1.65 & \multirow{2}{*}{$t(1324)=-6.94$} & \multirow{2}{*}{0.808} \\
\hline & Higher levels & 7.04 & 1.67 & & \\
\hline \multirow{2}{*}{ Desire and interest } & Lower levels & 9.05 & 2.61 & \multirow{2}{*}{$t(1309)=-4.54$} & \multirow{2}{*}{0.585} \\
\hline & Higher levels & 9.71 & 2.58 & & \\
\hline \multirow{2}{*}{ Arousal } & Lower levels & 10.71 & 2.46 & \multirow{2}{*}{$t(1184)=-5.21$} & \multirow{2}{*}{0.606} \\
\hline & Higher levels & 11.45 & 2.39 & & \\
\hline \multirow{2}{*}{ Orgasm } & Lower levels & 11.45 & 2.63 & \multirow{2}{*}{$t(1188)=-4.85$} & \multirow{2}{*}{$0.013^{*}$} \\
\hline & Higher levels & 12.18 & 2.47 & & \\
\hline \multirow{2}{*}{ Overall sexual functioning } & Lower levels & 44.44 & 8.08 & \multirow{2}{*}{$t(1113)=-5.725$} & \multirow{2}{*}{0.642} \\
\hline & Higher levels & 47.23 & 8.08 & & \\
\hline \multirow{2}{*}{$\begin{array}{l}\text { Satisfaction with physical } \\
\text { pleasure }\end{array}$} & Lower levels & 3.93 & 1.08 & \multirow{2}{*}{$t(1129)=-3.88$} & \multirow{2}{*}{0.434} \\
\hline & Higher levels & 4.18 & 1.07 & & \\
\hline \multirow{4}{*}{$\begin{array}{l}\text { Satisfaction with } \\
\text { emotional pleasure } \\
\text { Spending the rest of their } \\
\text { life with their current sex } \\
\text { life }\end{array}$} & Lower levels & 3.29 & 1.77 & \multirow{2}{*}{$t(1338)=-2.70$} & \multirow{2}{*}{0.436} \\
\hline & Higher levels & 3.56 & 1.78 & & \\
\hline & Lower levels & 3.01 & 1.76 & \multirow{2}{*}{$t(1338)=-3.25$} & \multirow{2}{*}{0.071} \\
\hline & Higher levels & 3.34 & 1.85 & & \\
\hline \multirow{2}{*}{$\begin{array}{l}\text { Importance of sex in the } \\
\text { overall life }\end{array}$} & Lower levels & 2.99 & 1.54 & \multirow{2}{*}{$t(1338)=-2.86$} & \multirow{2}{*}{0.144} \\
\hline & Higher levels & 3.23 & 1.60 & & \\
\hline
\end{tabular}

In order to determine a predictive relationship between mindfulness and sexual functioning and subjective sexual well-being, we created a linear regression to show that higher scores for sexual functioning (pleasure, desire and frequency, desire and interest, arousal, and orgasm) are predictors of higher levels of mindfulness $(R$ square $=0.610 ; p<0.001)$. This was also the case for subjective sexual well-being (satisfaction with physical pleasure, satisfaction with emotional pleasure, spending the rest of their life with their current sex life, and the importance of sex in overall life), which reports results that are predictors of higher levels of mindfulness ( $R$ square $=$ $0.610 ; p<0.001)$. 


\section{Discussion}

This study aimed to evaluate levels of mindfulness, sexual performance, and subjective sexual wellbeing, through the use of reliable instruments in order to improve the availability of information concerning the study of the links between mindfulness and areas of sexuality.

In this sample we found that the results for global mindfulness levels were moderately high, as expected, since the sample is normative and possesses no likelihood of presenting psychopathological symptomatology (Walach, Buchheld, Buttenmuller, Kleinknecht and Schmidt, 2006) that would affect mindfulness. The sample is also differentiated, consisting of highly educated and professional participants, as most participants have a university education and are employed. This is congruent with the fact that mindfulness is a multifaceted, heterogeneous, and comprehensive construct (Sternberg, 2000).

Despite the fact that the practice of meditation was not controlled, as Neves (2011) and Fernandes (2010) state, participants in this sample appear to have high levels of attention and acceptance that may facilitate more adaptive responses to performance situations and reduce emotional stress. This, in turn, leads to more positive states of mind and a better quality of life (Greeson, 2009; Greeson \& Brantley, 2009).

The fact that we found that men have higher levels of full attention than women might suggest that women are more vulnerable to psychological distress, which, according to Walach, Buchheld, Buttenmuller, Kleinknecht and Schmidt (2006), is a predictor of lower levels of mindfulness. At the same time, it appears that women are more likely to be socialized to internalize and express mental distress, seek support, and to use more dependent coping strategies of formal support and catharsis (Rabasquinho \& Pereira, 2007). Simultaneously, women benefit more from mindfulness-based interventions (Katz \& Toner, 2013). In contrast, men are more likely to be subjected to stereotyped gender roles that do not directly affect their ability to be alert and sensitive to different contexts (Rabasquinho \& Pereira, 2007). These results confirm the data obtained by Mezo and Baker (2012), who also found that men had higher levels of mindfulness due to the possible association between lower levels of mindfulness with depression and anxiety, which women are more likely to experience (Mezo \& Baker, 2012).

Having higher levels of mindfulness between the ages of 30 and 49 can be explained by the fact that participants in this age group are still protected from the susceptibility to cognitive decline associated with aging; yet, they are also more cognitively and emotionally mature than younger participants. As Bednar (2013) states, variables such as control beliefs associated with aging appear to be positively associated with higher levels of mindfulness, which requires us to accept that age can be a factor of interference on mindfulness. In fact, the results obtained in this study are similar 
to those obtained by Letho, Uusitalo-Malmivaara, and Repo (2015), which indicate that people between 38 and 68 years of age possess higher levels of mindfulness.

Regarding sexual function and subjective sexual well-being, the sample showed normative scores, which is consistent with other population-based studies (Laumann et al., 2006). Nevertheless, when comparing men and women, there were statistically significant differences in all dimensions except for "desire and interest" and "satisfaction with physical pleasure". These differences indicate that men score higher in all areas of sexual function. These differences can possibly be explained by biological, psychological, and social reasons that invite us to reflect on gender differences in specific social contexts. Portuguese society can be considered religious and conservative and tends to generate different social norms by gender. These norms are usually more permissive for men (Costa, Oliveira, Pereira \& Leal, 2015), which end up conditioning sexual functionality.

An increasing amount of research emphasizes the basic similarities in the sexual responses in men and women and the vast majority concludes that significant differences exist at every stage when comparing men with women. For example, some studies have shown that men have higher levels of sexual satisfaction than women, regardless of the socio-cultural context (Edward, Bryning \& Crane, 2014; Kabat-Zinn, 2003; Kabat-Zinn, 1990; Kabat-Zinn, Lipworth \& Burney, 1985). Thus, as in the present study, the average levels of satisfaction were generally lower in women than in men in all groups and in all aspects of subjective sexual well-being (Edward, Bryning \& Crane, 2014). These differences can be attributed to stereotypical socially constructed beliefs that regulate behavior and sexual attitudes by gender according to cultural norms (Mendonça, Silva, Arrudai, Garcia-Zapata \& Amaral, 2012; Dennerstein, Dudley \& Burger, 2001). These differences can also be ascribed to the anatomical structural and neuroanatomical differences between men and women that are still largely unexplored. As Basson (2000) and Carpenter, Nathanson, and Kim (2009) tell us, women seem to be more affected by emotional variables such as security or emotional closeness, and this may interfere with their thoughts, fantasies, or sexual behaviors.

Regarding the differences in sexual expression between age groups, we found that adult participants (30-49 years of age) have higher rates of sexual function and subjective sexual wellbeing. We expected these results, since it is accepted that there is a gradual decline in sexual responsiveness throughout the life cycle associated with changes in bodily function, hormonal changes, and frequency of sexual activity, even if these factors do not completely disappear with advancing age (Schick, 2010). On the other hand, although sexual activity is high among youth, it may not be accompanied by emotional stability and safety, thus affecting the subjective experience of sexual well-being.

With regard to associations between mindfulness, sexual functioning, and subjective sexual wellbeing, it was found that the only dimension where there were differences in comparing groups with 
higher and lower levels of mindfulness were the variables "pleasure" and "orgasm". These results may indicate how mindfulness seems to condition the sexual experience, working as a minimizer of anxiety that can specifically facilitate the experience of pleasure and orgasm (Garland, 20007, Coffey \& Hartman, 2008; Lucena \& Abdo, 2013). In the field of sexuality, the essence of mindfulness is reflected in cognitive, behavioral, and emotional awareness, a posture of acceptance, and a focus on the here and now of sexual sensations (McCarthy \& Wald, 2013). This is demonstrated by the effectiveness of mindfulness for the treatment of sexual dysfunction (Brotto \& Heiman, 2007). Hence, being sexually self-conscious has positive effects on sexual performance, as the self interferes positively in the arousal and pleasure process. This in turn, makes people more sensitive and aware and leads them to adopt a posture of openness and acceptance, in addition to promoting a more pleasurable sexuality (McCarthy \& Wald, 2013).

The linear regression model predicts a positive association between mindfulness, sexual function, and subjective sexual well-being. In fact, as Masters and Johnson (1966) state, attentional focus and minimal anxiety are fundamental for optimal sexual expression, and these ideas are congruent with mindfulness, which allows for the concentration on bodily sensations and the removal of disturbing thoughts (Goldmeier, 2013). Thus, we can anticipate that the benefits that mindfulness brings will be closely linked to the sexual dimensions of humans. Thus, the contribution of this research is to deepen the study of this field. As Nobre $(2009 ; 2010)$ states, there is a close impact between cognitive-emotional functioning, performance, and sexual functioning both in men and in women, thus suggesting an inherent predisposition to healthy sexuality based on the therapeutic prescriptions of mindfulness.

Mindfulness related to sexuality should be seen a personal responsibility, encompassing desire, pleasure, and sexual function. However, each person plays a crucial role in the mindfulness process. Therefore, in the realm of interpersonal relationships, its practice should be intended to promote significant improvements in the sexual experience, as reinforced by the results of this research. In this sense, mindfulness increases the levels of openness to the other, the clarity of perception of the relationship, and the degree of emotional closeness (Brown \& Ryan, 2003).

This study has some limitations, including the fact that the sample is highly differentiated and was collected by convenience over the Internet. Therefore, the results are not generalizable. In order to rectify these deficiencies, it would be appropriate to develop future studies with probability samples and also control groups, in order to manipulate the mindfulness experience as an experimental variable. It should be noted that the responses to questionnaires about intimate subjects, such as sexuality, may be influenced by factors such as inhibition, shame, or social desirability, which, not being controlled, may skew the results, although all the measures present good levels of internal consistency. 
Regardless, these results allow us to better inform technicians who work either in the area of mindfulness, or in the field of sexuality, about the importance of these two variables in promoting health, well-being, and quality of life in general.

Compliance with Ethical Standards

Funding: This study was not funded by any organization or grant thus careful consideration was given to all aspects of ethical nature.

Conflict of Interest: The authors declare that they have no conflict of interest.

\section{References}

Anderson, N. D., Lau, M.A., Segal, Z.V. \& Bishop, S.R. (2007). Mindfulness-based stress reduction and attentional control. Clinical Psychology and Psychotherapy, 14, 449-463;

Basson, R. (2000). The female sexual reponse: A diferente model. Journal of Sex \& Marital Therapy, 40, 51-65;

Bednar, J. L. (2013). Memory and aging: the role of mindfulness and control beliefs. Tese de Doutoramento da Universidade de artes e ciências: Brandeis;

Bishop, S.R., Lau, M., Shapiro, S., Carlson, L., Anderson, N.D., Carmody, J., Segal, Z.V., Abbey, S., Speca, M., Velting, D., \& Devins, G. (2004). Mindfulness: A Proposed Operational Definition. Clinical Psychology: Science and Practice, 11 (3), 230-241;

Brefczynski-Lewis, J. A., Lutz, A., Schaefer, H. S., Levinson, D. B., Davidson, R. J. (2007). Neural correlates of attencional expertise in long-term meditation practitioners. Proceedings of the National Academy of Sciences, 104 (7) 11483-11488;

Brotto, L. (2013). Mindful sex. Canadian Journal of Human Sexuality, 22(2), 63-68;

Brotto, L. Krychman, M. \& Jacobson, P. (2008) Eastern approaches for enhancing women's sexuality: mindfulness, acupuncture, and yoga. Journal of Sexual Medicine, 5, 2741-2748;

Brotto, L. A., \& Heiman, J.R. (2007). Mindfulness in sex therapy: applications for women with sexual difficulties following gynaecologic cancer. Sexual and Relationship Therapy, 22(1), 3-11; 
Brown, K., \& Ryan, R. (2003). The benefits of being present: mindfulness and its role in psychological well-being. Journal of Personality and Social Psychology, 84(4), 822-848;

Brown, K. W. \& Kasser, T. (2005). Are psychological and ecological well-being compatible? The role of values, mindfulness, and lifestyle. Social Indicators Research, 74, 349-368;

Buckstegge, K., Gouveia, M., Mafra, M. \& Bobato, S. (2009). Disfunções sexuais femininas: um estudo exploratório com um psicólogo que atua em âmbito clínico. Centro Científico Conhecer, $5(8)$;

Burpee, L. C. \& Langer, E. J. (2005). Mindfulness and marital satisfaction. Journal of Adult Development, 12, 43-51;

Carmody, J. (2009). Evolving conceptions of mindfulness in clinical settings. Cognitive Psychotherapy: An International Quarterly, 23(3), 270-280;

Carpenter, L.m Nathanson, C. \& Kim, Y, (2009) Physical women, emotional men: gender and sexual satisfaction in midlife. Archives of Sexual Behavior, 38, 87-107;

Carson, J. W., Carson, K. M., Gil, K. M., \& Baucom, D. H. (2004). Mindfulness-based relationship enhancement (MBRE) in couples. Behavior Therapy ,35, 471-494;

Chambers, R., Yee-Lo, B. C., \& Allen, N. B. (2008). The impact of intensive mindfulness training on attentional control, cognitive style, and affect. Cognitive Therapy and Research, 32, 303-322.

Christopher, M. S., Charoensuk, S., Gilbert, B. D., Neary, T. J. \& Pearce, K. L. (2009). Mindfulness in thailand and the United States: a case of apples versus oranges?. Journal of Clinical Psychology, 65(6), 590-612;

Coffey, K. A. \& Hartman, M. (2008). Mechanisms of Action in the Inverse Relationship Between Mindfulness and Psychological Distress. Complementary Health Practice Review, 13 (2), 79-91;

Coffey, K. A. \& Hartman, M. (2008). Mechanisms of action in the inverse relationship between mindfulness and psychological distress. Complementary Health Practice Review, 13 (2), 79-91;

Costa, P. A., Oliveira, R., Pereira, H. \& Leal, I. (2015) Adaptação dos inventários de sexismo moderno para Portugal: o inventário de sexismo ambivalente e o inventário de ambivalência em relação aos homens. Psicologia: Reflexão e crítica 28(1), 126-135;

Dennerstein, L., Dudley, E. \& Burger, H. (2001). Are changes in sexual functioning during midlife due to aging or menopause. Fertility and sterility, 76(3); 
Diamond, L. \& Huebner, D. (2012) Is good sex good for you? Rethinking sexuality and health. Social and Personality Psychology Compass, 6, 54-69;

Edwards, R. T., \& Bryning, L. (2013). Measuring the cost effectiveness of mindfulness - challenges and opportunities. Paper presented at the International Scientific Conference 2013, Mindfulness in Society Conference, Chester, UK. Retrieved from http://www.cmrpconference.com/index.php/past-conferences;

Edwards, R., Bryning, L. \& Crane, R. (2014) Design of Economic Evaluations of Mindfulness-Based Interventions: Tem Methodological Questions of which to be Mindful. Mindfulness;

Fernandes, M. (2010). Atenção plena e ansiedade do desempenho em músicos. Tese para obtenção do grau Mestre em Psicologia Clínica e da Saúde: Universidade do Algarve;

Franco, C., Mañas, I. \& Justo, I., (2009). Reducción de los niveles de estrés, ansiedad y depresión en docentes de educación especial através de un programa de mindfulness. Revista Educación Inclusiva, 2( 3), 11-22;

Frohlich, P., \& Meston, C. (2002). Sexual functioning and selfreported depressive symptoms among college women. Journal of Sex Research, 39, 321-325;

Garland, E. L. (2007). The Meaning of Mindfulness: A Second-Order Cybernetics of Stress, Metacognition, and Coping. Complementary Health Practice Review, 12 (1), 15-30;

Goldmeier, D. (2013). Mindfulness: A sexual medicine physician's personal and professional journey. Sexual and Relationship Therapy, 28(1-2), 77-83;

Greeson, J., \& Brantley, J. (2009). Mindfulness and anxiety disorders: developing a wise relationship with the inner experience of fear. Clinical handbook of Mindfulness, 171-188;

Greeson, J. M. (2009). Mindfulness research. Complementary Health Practice, 14(1), 10-18;

Grossman, P. (2010). Mindfulness for psychologists: Paying kind attention to the perceptible. Mindfulness, 1, pp. 87-97;

Gunarantana, H. (1992). Mindfulness in plain english. Wisdom Publications: Boston;

Hanh, N. T. (1976). The miracle of mindfulness: a manual for meditation. Beacon: Boston;

Hanh, T. N. (1999). The heart of the buddha's teaching. New York: Broadway; 
Hayes, S. C. \& Gregg, J. (2002). Functional contextualism and the self. Self-relations in the psychotherapy process. Washington, American Psychological Association, 391-307;

Hayes, S. C., \& Wilson, K. (2003). Mindfulness: Method and process. Clinical Psychology: Science and Practice, vol. 10, pp. 161-165;

Holas, P. \& Jankowski, T. (2013). A cognitive perspective on mindfulness. International Journal of Psychology, 48(3), 232-243;

Jha, A. P., Krompinger, J. \& Baime, M. (2007). Mindfulness training modifies subsystems of attention. Cognitive, Affective \& Behavioral Neuroscience, 7(2),109-119;

Justo, C., Manãs, I. \& Martínez, E. (2010). Mejora en algunas dimensiones de salud percebida en pacientes com fibromialgia mediante la aplicación de un -programa de meditación mindfulness. Psychology, Society, \& Education, 2(2), 117-130;

Kabat-Zinn, J. (1990). Full catastrophe living - using the wisdom of your body and mind to face stress, pain and illness. The Practice of Mindfulness, 4, 59-72;

Kabat-Zinn, J. (2003). Mindfulness-based intervention in context: past, present, and future. Clinical Psychology, Science and Practice, 10 (2), 144-156;

Kabat-Zinn, J. (2013). Keynote with Jon Kabat-Zinn - Mindfulnessbased interventions in medicine, psychology and beyond: transformation and healing at the confluence of science and dharma. Proceedings of the International Scientific Conference 2013, Mindfulness in Society Conference, Chester, UK. Retrieved September 19 2013, from http://www.cmrpconference.com/index.php/past-conferences;

Kabat-Zinn, J., Lipworth, L. \& Burney, R. (1985). The clinical use of mindfulness meditation for the self-regulation of chronic pain. Journal of Behavioral Medicine, 8 (2), 163-190;

Katz, D. \& Toner, B. (2013). A systematic of gender differences in the effectiveness if mindfulnessbased treatments for substance use disorders. Mindfulness, 4, 318-331;

Laumann, E. O., Paik A., Glasser D. B., Kang J., Wang, T., Levinson, B., Moreira, E., Nicolosi, A. \& Gingell, C. (2006) A cross-national study of subjective sexual well-being among older women and men - findings from the global study of sexual attitudes and Behaviors. Sexual Behavior, 35(2), 14516 ;

Laumann, E., Paik, A., \& Rosen, R. (1999). Sexual dysfunction in the United Sates: prevalence and predictors. American Medical Association, 281, 537-544; 
Lazaridou, A. \& Kalogianni, C. (2013). Mindfulness and sexuality. Sexual and Relationship Therapy, 28(1-2), 29-38;

Lehto, J., Uusitalo-Marmivaara, L. \& Repo, S. (2015). Measuring mindfulness and well-being in adults: the role of age and meditation experience. Happiness \& Well-Being, 3(1), 30-40;

Lucena, B. \& Abdo, C. (2013) O papel da ansiedade na (dis)função sexual programa de estudos em sexualidade (ProSex). Diagn Tratamento, 18(2), 94-8;

Lucena, B. \& Abdo, C. (2013) O papel da ansiedade na (dis)função sexual. Diagn Tratamento 18(2), PP. 94-108;

Maroco, J. \& Garcia-Marques, T. (2006). Qual a fiabilidade do alfa de Cronbach? Questões antigas e soluções modernas?. Laboratório de Psicologia, 4(1), 65-90;

Masters, W. H. \& Johnson, V. E. (1966) Human sexual response. New York: Bantam Books

McCarthy, B. \& Wald, L. (2013). Mindfulness and good enough Sex. Sexual and Relationship Therapy, 28(1-2), 39-47;

McCreary, S. \& Alderson, K. (2013). The Perceived effects of practising meditation on women's sexual and relational lives. Sexual and Relationship Therapy, 28(1-2), 105-119;

Mendonça, C., Silva, T., Arrudai, J., García-Zapata, M. \& Amaral, W. (2012). Função Sexual Feminina - Aspetos normais e patológicos, prevalência no Brasil, diagnóstico e tratamento. Feminina, 4(4);

Mezo, P. \& Baker, R. (2012). The moderating effects of stress and rumination on depressive in women and men. Stress Health, 4, 333-339;

Nanamoli, B., \& Bodhi, B. (1995). The middle length discourses of the Buddha: The majjhima nikaya. Boston:Wisdom Publications;

Neves, C. (2011). A relação entre mindfulness, auto-compaixão, vergonha e psicopatologia em praticantes e não praticantes de meditação/yoga. Dissertação Apresentada ao ISMT para obtenção do Grau de Mestre em Psicologia Clínica. Coimbra: Instituto Superior Miguel Torga

Nobre, P. J. (2009). Determinants of sexual desire problems in women: testing cognitive-emotion model. Journal of sex and marital therapy 35(5), 360-377; 
Nobre, P. J. (2010). Psychological determinantes of erectile dysfunction: testing a cognitiveemotional model. Journal of sexual medicine 7(4) 1429-1437;

Oberg, K., Fugl-Meyer, K., \& Fugl-Meyer, A. (2002). On sexual well-being in sexually abused swedish women: epidemiological aspects. Sexual and Relationship Therapy, 17, 329-341;

Papali, D., Olds, S. \& Feldman, R. (2008). Human Development. New York;

Rabasquinho, C. \& Pereira, H. (2007). Género e saúde mental: uma abordagem epidemiológica. Análise Psicológica, 3, 439-454;

Schick, V., Herbenick, D., Reece, M., Sanders, S. A., Dodge, B., Middlestadt, S. \& Fortenberry, J. D. (2010). Sexual behaviors, condom use, and sexual health of americans over 50: implications of sexual health promotion for aging adults. The Journal of Sexual Medicine, 7(5), 315-329;

Shapiro, S., \& Schwartz, G. E. (2005). The role of intention in self-regulation: toward intentional systemic mindfulness. Handbook of self-regulation, 253-273;

Siegel, R. D., Germer, C. K. \& Olendzki, A. (2009). Mindfulness: What is it? Where did it come from?. Clinical Handbook of Mindfulness, 17-35;

Sillifant, B. (2007). A conceptual basis for the refinement of an operational definition of mindfulness. Tese de obtenção de grau de aconselhamento, Universidade de Massey, Nova Zelândia;

Simón, V. (2011) Aprender a practicar mindfulness y abrir el corazón a la sabiduría y la compasión. Espanha:Barcelona;

Sternberg, R. J. (2000). Images of mindfulness. Journal of Social Science Issues, 56(1), 11-26;

Tang, Y., Ma, Y., Wang, J., Fan, Y., Feng, S., Lu, Q., Yu, Q., Sui, D., Rothbart, M. K., Fan, M. \& Posner, M. I. (2007). Short-term meditation training improves attention and self-regulation. Proceedings of the National Academy of Sciences, 104(43), 17152-17156;

Traeen, B. \& Schaller, S. (2010). Subjective sexual well-being in a web sample of heterosexual norwegians International Journal of Sexual Health, 22, 180-194;

Walach, H., Buchheld, N., Buttenmuller, V., Kleinknecht, N. \& Schmidt, S. (2006). Measuring mindfulness - the freiburg mindfulness inventory (FMI). Personality and Individual Differences, 40, 1543-1555; 
Weinstein, N., Brown, K.W. \& Ryan, R.M. (2009). A multi-method examination of the effects of mindfulness on stress attribution, coping, and emotional well-being. Journal of Research in Personality, 43, 374-385. 


\section{Capítulo 3 - Discussão Geral}

O $2^{\circ}$ ciclo em Psicologia Clínica e da Saúde da Universidade da Beira Interior está estruturado de acordo com o EUROPSY e objetica a preparação do estudante para um exercício profissional independente como Psicólogo na área Clínica e da Saúde ou para a pressucação de estudos num $3^{\circ}$ ciclo. Deste modo, o curso pretende desenvolver competências tais como a compreensão aprofundada de modelos teóricos, construtos e processos, a aplicação de métodos, técnicas e instrumentos de avaliação e de intervenção psicológica, a compreensão e aplicação de metodologias de investigação e ainda o comprometimento com obrigações deontológicas e éticas de crítica de produção científica. 0 objetivo primordial da prática profissional de psicologia passa por desenvolver e aplicar princípios, conhecimentos, modelos e métodos de uma forma ética e científica, tendo em vista a promoção do desenvolvimento, bem-estar e eficácia dos indivíduos, grupos, organizações e sociedade de forma geral. É ainda de realçar que qualquer disciplina, que queria ser considerada como ciência, deve basear-se em conceitos e esquemas concetuais que foram desenvolvidas como resultado da experimentação e das observações, obtidas através do método científico. Neste sentido, para a obtenção do grau de Mestre em Psicologia Clínica e da Saúde pela Universidade da Beira Interior, é indispensável que seja desenvolvida uma panóplia de competências de trabalho em três áreas fulcrais: na avaliação, na intervenção e na investigação psicológicas.

Congruente com o referido, a presente dissertação visou o desenvolvimento de competências na área de investigação científica. Assim e indo de encontro com o Diploma do Psicólogo Europeu, o psicólogo deve desenvolver um conjunto de valências, que se dividem em dois grupos principais: as competências primárias e as competências secundárias. 0 primeiro grupo abrange várias competências que se agrupam em categorias e que, todo e qualquer psicólogo deve ser capaz de demonstrar. Estas estão relacionadas com os papéis profissionais, nomeadamente, (1) especificação de objectivos, (2) avaliação prévia, (3) desenvolvimento, (4) intervenção, (5) avaliação posterior e (6) comunicação.

Por seu turno, o segundo grupo - competências secundárias - envole também uma panóplia de competências cruciais para o desenvolvimento de uma boa prática profissional. Neste sentido, uma das primeiras competências é a estratégia profissional, ou seja, deve ser escolhida uma estratégia adequada para lidar com as adversidades que aparecem ao longo do percurso de cada um, com base numa reflexão acerca da sua situação profissional, bem como as suas próprias competências. De seguida, realça-se o desenvolvimento profissional contínuo, mantendo assim uma atualização e desenvolvimento da sua formação e competências acompanhando as mudanças e as exigências da 
profissão de psicólogo. Devem ainda ser estabelecidos e mantidos relacionamentos com outros profissionais, bem como com organizações relevantes. Num outro prisma e indo de encontro também com a presente dissertação, torna-se crucial a investigação e o desenvolvimento de novos trabalhos que objetivam uma compreensão aprofundada acerca de determinada área o que, consequentemente, permite satisfazer as necessidades dos indivíduos. Deve ainda haver uma garantia de qualidade, ou seja, deve estabelecer-se um sistema de garantia de qualidade para a prática como um todo, obedecendo assim a um conjunto de normas éticas e morais. Por fim, mas não menos importante deve ser feita, constantemente, uma auto-reflexão crítica acerca da sua prática profissional e acerca das competências pessoais, de forma a poder limar algumas arestas, melhorar o seu trabalho e, desta forma, contribuir para um aumento da satisfação e bem-estar da sociedade.

Neste seguimento e tendo como foco a investigação, que está presente ao longo desta dissertação, é de realçar que cabe ao investigador produzir conhecimento científico através da realização de estudos planeados com rigor científico e de um modo que confira cientificidade à investigação. Indo de encontro com Pais Ribeiro (2002), a lei portuguesa define que uma das funções do psicólogo que trabalha ou pretende trabalhar em contexto de saúde, passa pela investigação. Assim, a presente dissertação e submissão do artigo científico pretende ser um contributo para a atividade científica na área, não só da psicologia, mas também pretende informar técnicos que trabalhem na área de mindfulness e da sexualidade, alertando assim para a importância de trabalhos conjuntos nestas duas variáveis, de forma a promover o bem-estar a saúde e a qualidade de vida em geral.

Indo de encontro com o preconizado anteriormente foi desenvolvida a presente investigação que foi aprovada pela Comissão Científica do Departamento de Psicologia da Univerisdade da Beira Interior. Esta é parte integrante do $2^{\circ}$ ciclo de estudos em Psicologia Clínica e da Saúde e visou o desenvolvimento das competências supracitas, de forma a permitir o seu desenvolvimento, nomeadamente ao nível da investigação e da auto-reflexão. A realização da presente dissertação levou ao desenvolvimento e à consolidação de inúmeras competências transversais, tais como a tomada de decisão, a análise crítica, a integração e aplicação de informação científica, a aprendizagem auto-orientada, a comunicação oral e escrita e ainda a urilização avançada de recursos informáticos. Neste sentido, ao longo deste último ano letivo, antes de mais, evidenciaram-se competências de gestão de tempo, uma vez que houve constatemente prazos a cumprir e então, desde início, o tempo teve de ser gerido de forma a garantir o cumprimento dos prazos previamente estabelecidos. Por seu turno, a pesquisa e ultização de informação científica de forma correta foi outra das competências transversais que foram desenvolvidas, uma vez que existe um grande número de informação acerca dos temas e, nem sempre foi fácil a junção e integração da grande quantidade do estado de arte existente. 
Indo de encontro com o referido, não poderá deixar de ser realçado o facto de todo o trabalho de investigação aqui exposto, ter sido um trabalho de equipa, o que proporcionou uma grande partilha de experiências pessoais, discussão/debate acerca das grandes dificuldades encontradas ao longo deste percurso. Para além do referido, foram desenvolvidas formas de comunicação da aprendizagem das competências de investigação psicológica que envolveu um estudo empírico, representando assim um contributo relevante para a área de atuação.

Como já tem vindo a ser referido ao longo do presente trabalho, existe um número considerável de estudos acerca de mindfulness, funcionamento sexual e bem-estar sexual subjetivo, contudo, poucos são aqueles que fazem uma associação entre estes três construtos. Inicialmente analisaramse os níveis de mindfulness dos 1416 participantes e verificou-se que estes apresentam indicadores moderadamente elevados para os vários domínios. Tendo em consideração os géneros, verificou-se que os homens, apresentam níveis mais elevados de mindfulness, de funcionamento sexual e ainda, na grande maioria das variáveis, de bem-estar sexual subjetivo. Por sua vez, no que refere às diferenças entre as faixas etárias, verificaram-se níveis mais elevados de mindfulness, de funcionamento sexual e bem-estar sexual subjetivo na faixa etária entre os 30 e os 49 anos. Deste modo, no presente estudo foi ainda realizada uma relação preditiva entre as três variáveis supracitas e verificou-se que o mindfulness, ou seja, um estado de atenção plena e foco no momento presente, sem fazer qualquer juízo de valor é preditor de uma exepriência sexual mais satisfatória.

Assim, com a presente dissertação pretende-se contribuir para o aumento dos estudos relativos a estes temas e ainda alertar para a importância da existência de mais trabalhos que articulem as três variáveis - mindfulness, funcionamento sexual e bem-estar sexual subjetivo - oferencendo informação pertinente para todos os técnicos que trabalhem nas referidas àeras. Para além do referido, alerta-se ainda para a importância de, em futuros estudos, tendo em conta a temática, ponderar a realização de estudos mais qualitativos com amostras probabilísticas e também com grupos de controlo, manipulando a experiência de mindfulness como variável experimental. 
Anexos 
Anexo 1: Anexo Teórico 


\section{Mindfulness}

\section{Definição}

O termo mindfulness é a tradução para o inglês do termo "Sati" em Pali que significa significa recordar, reconhecer e estar consciente de forma intencional. Significa ainda uma mente vigilante e lúcida, atenção plena, estar alerta e auto-consciente, (Sillifant, 2007; Siegel, Germer \& Olendzki, 2009; Simón, 2011). Historicamente, a atenção plena é definida como o "coração" da meditação budista (Thera, 1962) e reside no núcleo dos ensinamentos do Buda (Gunaratana, 1992; Hanh, 1999; Nanamoli \& Bodhi, 1995; Hanh, 1976). Com o passar do tempo, a própria palavra inglesa sofreu uma evolução no seu significado, devido à investigação que vai sendo realizada acerca do tema e que se traduz num aumento de publicações acerca do mesmo (Simón, 2011).

Quando se fala em mindfulness, faz-se referência ao termo que se pode traduzir como "Consciência Plena" ou "Atenção Pena", isto é, é um estado de total consciência/atenção que se pode desenvolver através de díspares técnicas. Uma das grandes vantagens da prática de mindfulness é que esta não depende de nenhuma ideologia ou crença específica. Apesar de, em diferentes estudos, o mindfulness estar bastantes vezes associado à tradição budista, qualquer pessoa pode experimentar os seus benefícios (Kabat-Zinn, 1990). Neste sentido, o mindfulness pode utilizar-se para descrever três coisas: (1) um constructo teórico; (2) uma prática para desenvolver o mindfulness, como a meditação; (3) um processo psicológico (estar consciente - mindful) (Simón, 2011).

De acordo com a perspetiva budista, o mindfulness engloba uma panóplia de dimensões cognitivas, éticas e emocionais (Grossman, 2010), relacionando-se com as qualidades particulares de atenção e de consciência que podem ser cultivadas e desenvolvidas através da meditação (Kabat-Zinn, 2003). Este constructo foi definido como sendo um processo de trazer a atenção plena para a experiência atual e momento a momento (Marlatt \& Kristeller, 1999; Langer, 1992; Neves, 2011). A presente definição implica que as funções executivas e os processos atencionais estejam presentes no início de um evento e se mantenha esse estado de mindfulness ao longo do tempo (Holas \& Jankowski, 2013).

É ainda de referir que a meditação foi introduzida no Ocidente na década de 60 e, com o passar do tempo, levou a uma crescente procura enquanto prática pessoal e a um interesse científico debruçado sobre a psicologia cognitivo-comportamental (Neves, 2011). Esta é descrita na literatura como sendo um treino de atenção plena e de consciência no momento presente e é, concomitantemente, associada a um bem-estar físico, mental e emocional (Shapiro \& Schwartz, 2005; Neves, 2011). Neste sentido, é de realçar que a prática de meditação pode ser dividida em duas formas (1) Concentrativa: onde o treino de atenção incide apenas sobre um foco tal como a 
respiração, contagem sincronizada da respiração ou algum som e (2) Mindfulness: Consciência da experiência do momento presente, com uma atitude de aceitação, em que não é feito nenhum tipo de julgamento. A meditação concentrativa está relacionada com as funções de monitorização e orientação enquanto a meditação mindfulness está mais relacionada com um estado de alerta (Neves, 2011), sendo que ambas se caraterizam por um tipo de meditação passiva, isto é, sentada e silenciosa (Jha, Krompinger \& Baime, 2007).

Nos últimos 40 anos estas tradições budistas criaram raízes no ocidente e, atualmente, tem sido cada vez mais utilizada na prática diária de indivíduos de todas as partes do mundo (Kabat-Zinn, 2003). Este fenómeno de expansão da prática de mindfulness representa uma mudança cultural que está ainda na sua essência (Kabat-Zinn, 2003). Num primeiro momento, o mindfulness é caraterizado pela criação contínua de novas categorias de interpretação de vivências, de forma a prestar atenção plena ao momento, à situação e ao contexto (Langer, 1989). O processo de mindfulness resulta também numa postura de abertura a novas informações e num foco sobre os processos mais complexos (Langer, 1989; Brotto, Krychman \& Jacobson, 2008). A partir da década de 90 este passou a ser parte integrante de algumas terapias comportamentais contextualistas (Zettle \& Hayes, 1986; Linehan, 1987) tornando-se numa característica central destas (Hayes, 2004).

Aparentemente o conceito de mindfulness parece ser algo simples, contudo, a sua descrição e caraterização não é consensual entre os investigadores (Bishop et al., 2004). Esta divergência de opiniões deve-se ao facto do mindfulness ser um constructo multifacetado, o que torna difícil a sua caraterização e operacionalização (Bishop, 2002), por isso, a definição varía bastante em função do seu contexto (social, psicológico, clinico ou espiritual) e em função da perspetiva de análise (clínico, investigador ou praticante) (Singh et al,, 2008; Neves, 2011). Deste modo, é difícil reunir consenso quando se refere ao esclarecimento e à distinção dos componentes essenciais do mindfulness, bem como aos processos psicológicos envolvidos neste processo, aàs suas tecnologias e resultados (Bishop et al., 2004; Sillifant, 2007). Assim, este é encarado por alguns como sendo uma técnica, um método e um processo psicológico e por outros como sendo o próprio resultado desse processo psicológico (Hayes \& Wilson, 2003).

Esta lacuna na definição de mindfulness acarreta consequências, nomeadamente uma elevada ambiguidade à volta deste tema, o que dificulta a determinação dos ingredientes ativos do mindfulness, assim como dos mecanismos que produzirão a mudança (Dimidjian \& Linehan, 2003). Como já tem vindo a ser referido, um pouco por todo o mundo a pesquisa acerca de mindfulness está em expansão (Williams \& Kabat-Zinn, 2011 cit in Edwards, Bryning \& Crane, 2014) e, por isso, tem sido solicitada mais investigação nesta área (Edwards \& Bryning, 2013; Kabat-Zinn, 2013). 
Uma das primeiras pioneiras a debruçar-se sobre este conceito (Langer, 1989 cit in Borynski, 2006) definiu-o como sendo um estado mental flexível em que se está envolvido de forma ativa no presente e se observam os novos fenómenos, estando sensível ao contexto (Fletcher \& Hayes, 2005). Deixando de lado os estados emocionais e as sensações físicas, classificou-o como sendo um constructo metacognitivo e multidimensional (Gregório \& Pinto-Gouveia, 2011).

Um pouco mais tarde e após o conceito de mindfulness passar por várias definições, Kabat-Zinn (2003) aponta como uma falha grave o facto de serem ignoradas caraterísticas deveras importantes e que, seriam as mais difíceis de definir. Entre elas encontra-se a aceitação, o não julgamento, o conhecimento consciente no momento presente, a atenção e a intenção, considerando que são componentes essenciais da definição e da própria experiencia (Germer, 2005; Fernandes, 2010). Assim, o mindfulness é definito por Kabat-Zinn (1990) como uma forma específica de atenção plena, isto é, um modo de concentração no momento presente, de forma intencional e sem julgamentos. Neste sentido, a concentração no momento presente significa estar apenas concentrado no presente e não estar em contato com lembranças do passado ou com pensamentos acerca do futuro (Neves, 2011). O mesmo autor considera que as pessoas funcionam, de certa forma, em modo de "piloto automático" e por isso, a prática de mindfulness pretende trazer a atenção plena para a ação do presente (Neves, 2011).

O mindfulness envolve a observação constante a mudanças internas e a estímulos externos que possam surgir (Baer, 2003). É então definido como a consciência do conhecimento que emerge ao prestar atenção deliberada, no momento presente e sem realizar qualquer juízo valorativo sobre a própria experiência, permitindo desta forma a focalização da mente com uma maior consciência/atenção plena, autoconhecimento e redução dos pensamentos automáticos (Brefczynski-Lewis, Lutz, Schaefer, Levinson \& Davidson, 2007; Brown \& Ryan, 2003; Shapiro, Schwartz \& Santerre, 2005).

A atenção plena, para além de ser considerada um atributo da consciência (Brown \& Ryan, 2003) é também vista como umas das aptidões e/ou propriedades mentais básicas (Rothweel, 2006). Assim, este conceito de atenção plena é descrito como um modo de estar, uma forma de estar atento, de estar desperto e de perceção ou apreensão dos acontecimentos e conteúdos mentais (perceções, sensações, cognições e afetos) no momento-a-momento (Kabat-Zinn, 1990; Gregório \& PintoGouveia, 2011). A atenção plena, além de ser o foque no presente, refere-se também a uma atitude mental de curiosidade, bem como à suspensão da tendência da mente para fazer avaliações, classificações e julgamentos (Fernandes, 2010). Neste sentido, emerge assim a recetividade e a aceitação como sendo estes um dos aspetos cruciais do conceito (Brown \& Ryan, 2003). Quando o sujeito adota conceitos lineares, segue regras ou informações acumuladas no passado e confia em hábitos, está a simplificar e a facilitar a navegação no ambiente social. Apesar do referido, esta 
simplificação é prejudicial em diversas situações, pois o não prestar atenção plena ao contexto e não integrar novas informações pode levar a erros importantes de julgamento (Langer, 1989).

A atenção plena é assim um fator mental encarregue da observação sistemática do fluxo dos objetos da mente, ou seja, é a experiencia de ter contato com o momento presente da atividade da mente. Durante a prática de mindfulness o praticante pode experimentar as mudanças que ocorrem de forma constante no que concerne aos fenómenos, sem ser arrastado pelos atos mentais que contaminam a mente (Namto, 1989). Assim, a atenção plena traduz-se na capacidade de uma pessoa ser consciente em cada situação da sua vida, focando-se em desenvolver vários tipos de controlo e de sabedoria, baseados na capacidade de relaxar, prestar atenção, adquirir consciência e ter uma visão profunda. Trata-se aqui de uma observação do próprio indivíduo e do mundo que o rodeia, aprendendo a lidar com próprios corpos, ideias, sensações e perceções e, desta forma, adquirindo experiência para serem capazes de relativizar os acontecimentos de vida e o envolvimento nos mesmos (Fonseca, 2012). É aqui de realçar que a experiência difere da informação teórica e/ou concetual relacionada com a realidade o que, por sua vez, permite entender que o presente é o único momento para viver e em que realmente se pode fazer alguma coisa (Namto, 1989).

Indo de encontro com o referido, durante a prática da atenção plena são realçados cinco fatores que estão relacionados com a atitude e com o compromisso: (1) Suspender o juízo de valor; (2) Cultivar a paciência; (3) Manter a mentalidade de principiante (atitude recetiva a coisas novas); (4) Reforçar a confiança e (5) Aceitação (ver as coisas como são no presente) (Fonseca, 2012).

Congruente com o supracito, a atenção plena é descrita no modelo cognitivo como sendo uma construção individual onde estão presentes: (1) Estado intencional da meta-consciência (consciência de estar consciente de algo) e (2) atitude aberta e recetiva para o conteúdo da experiência (Holas \& Jankowski, 2013). Apesar desta ser descrita, de modo geral, como uma forma de meta-consciencia de todos os elementos de experiencia, é considerada ainda importante a ação dos componentes de mindfulness, tais como aceitação, acolhimento e abertura à experiência (Holas \& Jankowski, 2013). Por seu turno, do ponto de vista das ciências comportamentais, a atenção plena pode ser vista como uma disciplina da consciência (Walsh, 1980), assemelhando-se a uma forma de arte que se desenvolve ao longo do tempo e que pode ser reforçada através da prática regular disciplinada (Kabat-Zinn, 2003) e que se tornou de extrema importância para a prática clínica contemporânea (Vandenberghe \& Assunção, 2009).

Alguns investigadores debatem-se sobre a forma como a atenção plena se relaciona com outros constructos psicológicos (Spencer-Oatey, 2013) e realmente parece estar relacionado com habilidades cognitivas e de inteligência, num sentido lato. Assim, tendo em conta que o mindfulness exerce uma relação sobre a consciência, este parece estar correlacionado, de certa forma, com as 
capacidades cognitivas. Outros defendem que, ao invés de ser uma capacidade cognitiva, o mindfulness pode ser encarado como um traço de personalidade (Spencer-Oatey, 2013). No entanto, independentemente de quais os constructos psicológicos inerentes a este processo, pode dizer-se que a consciência de que um mesmo estímulo ambiental pode ser tratado de diferentes maneiras, dependendo do seu contexto, é a essência da consciência plena (Spencer-Oatey, 2013).

Apesar do mindfulness ser, de uma forma geral, descrito como uma espécie de metaconsciência, é importante reconhecer que a atitude do indivíduo (aceitação, abertura à experiência) é algo imprescindível neste processo. Neste sentido, o processo de mindfulness implica que as funções executivas e os processos de atenção estejam ativos (Sillifant, 2007; Marlatt \& Kristeller, 1999, cit in Baer, 2003.).

É de realçar que existem na literatura inúmeras definições e teorias acerca do conceito de mindfulness, contudo, é de realçar que as definições contemporâneas existentes na literatura psicológica advêm de algum consenso por parte de especialistas (Bishop, et al, 2004), outras resultam da análise de diversas medidas da atenção plena (Baer, et al., 2006), outras foram tidas em conta para grupos específicos (Linehan, 1993) e outras resultaram ainda de programas de investigação progressivos que testaram, de forma sistemática, processos psicológicos (Fletcher \& Hayes, 2005). No entanto, os esforços reúnem-se no sentido de desenvolver uma base científica que sintetize a prática de mindfulness (Cayoun, 2006).

\section{Axiomas, fundamentos e componentes do mindfulness}

Com o intuito de entender como realmente o mindfulness produz mudanças, foram propostos três axiomas: (1) A intenção; (2) A atenção e (3) A atitude (Shapiro, Carlson, Astin \& Freedman, 2006). Estes três axiomas não são processos separados ou fases, mas sim aspetos interligados num processo cíclico que ocorrem em simultâneo (Shapiro, Carlson, Astin \& Freedman, 2006). Os três axiomas referidos são também componentes fundamentais da atenção plena (Shapiro, Carlson, Astin \& Freedman, 2006) e estes respondem de forma direta ou indiretamente a uma variedade de situações e de mudanças (Shapiro, Carlson, Astin \& Freedman, 2006). Com base nos comportamentos, são ainda postulados mecanismos de atenção que surgem de forma intencional: (1) Autorregulação; (2) Clarificação de valores; (3) Flexibilidade cognitiva, emocional e comportamental e (4) Exposição (Shapiro, Carlson, Astin \& Freedman, 2006).

Neste seguimento, existem então três mecanismos mediadores e essenciais para que o mindfulness tenha efeitos positivos: (1) perceção das experiências internas (descentramento) (Fresco et al., 2007; Shapiro, Carlson, Astin \& Freedman,, 2006); (2) Diminuição da atenção auto-focada (Leary, 
Adams \& Tate, 2006) e (3) Atitude carinhosa e amável em relação a si próprio, isto é, autocompaixão (Neff, 2003).

Para além dos axiomas e dos mecanismos referidos, ainda existem quatro fundamentos da atenção plena aos quais não poderia deixar de fazer aqui referência. Em primeiro lugar, observar o corpo no corpo, isto é, ver aquilo que faz com que o corpo se mexa. Isto porque, entendendo como o corpo se move, é fácil entender que a mente também tem movimentos e pode observar-se a atividade da mente que realiza determinada ação e desta forma, pode ser captada a intenção que impulsa a mente a agir. Ainda tem lugar a observação da sensações nas sensações, isto é, observar a forma como sentimos as coisas como sendo agradáveis, desagradáveis ou neutras e, neste sentido, podem ser observados os objetos mentais nos próprios objetos mentais. Por outras palavras, o mindfulness pretende desmistificar as sensações mentais, como a alegria, apatia, preocupação, calma, medo, dúvida, entre outras atitudes mentais que possam surgir (Namto, 1989).

Como tem vindo a ser descrito, o mindfulness contem diversos componentes, como a abertura à novidade, o estado de alerta, a sensibilidade a diferentes contextos, a consciência implícita e explícita de múltiplas perspetivas e ainda a orientação no presente (Spencer-Oatey, 2013), o que se reflete num constructo multifacetado e heterogéneo (Sternberg, 2000). Neste seguimento, Bishop e colaboradores (2004) introduziram a esta definição mais dois componentes: a autorregulação da atenção (com o intuito de mantê-la na experiência imediata, permitindo o reconhecimento de acontecimentos mentais que ocorrem no momento) e a orientação para a experiência do momento presente (adotando uma postura de curiosidade, de abertura, de aceitação e de não-julgamento) (Bishop, et al., 2004; Walach, Buchheld, Buttenmuller, Kleinknecht \& Schmidt, 2006; Sillifant, 2007).

Existe um interesse cada vez maior acerca do mindfulness na psicologia, contudo, há uma disparidade bastante grande de opiniões no que concerne à compreensão e aplicação dos processos de mindfulness por este ser um fenómeno complexo. Neste sentido, denota-se alguma falta de base teórica no que refere aos componentes, mecanismos e aos resultados do mindfulness, independentemente da abordagem que é feita. Torna-se fulcral uma operacionalização de mecanismos e/ou conceitos relacionados com a atenção plena, uma vez que, sem esta visão empírica, se torna difícil a existência de uma linguagem comum e bases sólidas para uma pesquisa nesta área (Sillifant, 2007).

\section{Intervenção}

Apesar de existirem bastantes avanços no conhecimento no que concerne aos benefícios da intervenção baseadas em mindfulness, parece ainda ser um tema pouco estudado e haver alguma 
limitação na sua compreensão enquanto fenómeno (Sillifant, 2007). Tal facto justifica-se pelo motivo de existirem na literatura inúmeras definições que em bastante diferem (Cardaciotto, 2005 cit in Sillifant, 2007) e, por isso, ainda não existe uma definição operacional que seja aceite pela comunidade científica. Neste seguimento e indo de encontro com o já referido anteriormente, o mindfulness emergiu de duas tradições distintas de pensamento. A primeira surgiu na psicologia experimental, através da pesquisa elaborada por Ellen Langer e a segunda emergiu do trabalho de Jon Kabat-Zinn onde introduziu na prática clínica a meditação budista. Apesar de serem duas abordagens distintas, ambas partilham entendimento acerca do sofrimento humano e promovem soluções semelhantes para as problemáticas dos seus praticantes (Vandenberghe \& Assunção, 2009).

Não obstante, o mindfulness ganhou destaque nas terapias cognitivo-comportamentais nas últimas décadas, uma vez que as pessoas têm cada vez mais necessidade de aprender a lidar com as próprias emoções (Vandenberghe \& Assunção, 2009). É de realçar que a intervenção baseada em mindfulness é isenta de fatores culturais, religiosos ou ideológicos associados ao budismo. Esta pretende apenas potenciar métodos eficazes para que o sujeito seja capaz de enfrentar, explorar e avaliar os níveis de sofrimento do corpo e da mente, compreendendo também o potencial poder inerente à conexão entre ambos (Kabat-Zinn, 2003). É de referir que o mindfulness não é considerado uma técnica de relaxamento ou de gestão do humor, mas sim uma forma de treino mental que ajuda a reduzir a vulnerabilidade cognitiva (Bishop et al., 2004). É ainda proposto por alguns autores que o mindfulness é uma forma de consciência que é evocada quando a atenção é regulada (Bishop et al., 2004). Assim, o mindfulness é visto muito mais como um estado do que como um traço de personalidade e é ainda encarado como um processo psicológico e como uma habilidade que pode ser desenvolvida com a prática (Bishop et al., 2004).

A redução de stresse baseada em mindfulness foi uma das primeiras formas de intervenção e traduzse num programa clínico desenvolvido por Kabat-Zinn num contexto behaviorista dirigido a populações com um largo espetro de desordens relacionadas com a dor crónica e com o stresse (Fernandes, 2010). Teasdale, Segal e Williams (1995) desenvolveram também a terapia cognitiva baseada em mindfulness que assentava no pressuposto de que as competências do controlo da atenção poderiam auxiliar os sujeitos a modificar a sua relação com o padrão habitual de pensamentos automáticos disfuncionais (Fernandes, 2010). Na base desta intervenção está uma corrente behaviorista e cognitivista e são incorporados vários elementos como a qualidade da atenção, a curiosidade e a aceitação (Rothwell, 2006). Pretende-se neste programa treinar, de forma sistemática, uma observação imparcial dos pensamentos e sentimentos, com o intuito de promover um relacionamento descentrado destes, passando a ser encarados como acontecimentos mentais e aspetos da experiência do momento (Fernandes, 2010). A terapia cognitiva baseada em mindfulness teve as suas primeiras evidências empíricas há mais de 20 anos e surgiu associada à dor crónica (Kabat-Zinn, 1982; Kabat-Zinn, Lipworth \& Burney, 1985). Neste sentido, denotou-se que 
com a presente terapia os doentes melhoraram de forma significativa no nível da dor e em outros sintomas médicos, nomeadamente, em sintomas psicológicos (Fernandes, 2010).

Mais tarde foi introduzida a terapia cognitivo-comportamental que foi marcada por novos desenvolvimentos designados como a "Terceira geração da Terapia Comportamental" por combinar técnicas cognitivo-comportamentais com o mindfulness e a aceitação incondicional dos acontecimentos (Hayes, 2004). Ao contrário das terapias cognitivas, a ênfase não é colocada no conteúdo ou na reestruturação dos pensamentos e esquemas cognitivos, mas sim na dinâmica e no processo (Fernandes, 2010). Estas novas abordagens tentam sobretudo dar ênfase ao contexto, à sua função e à relação que os indivíduos têm com os seus pensamentos e emoções (Singh et al., 2008). A referida terapia baseada em mindfulness pretende então transformar a perspetiva que produz 0 significado em relação a determinada crença ou sentimento (Hayes \& Gregg, 2002).

Com o passar do tempo, foram surgindo indicações de que a atenção plena pode ser um preditor de vários indicadores como saúde, bem-estar, qualidades adaptativas, flexibilidade cognitiva, inteligência emocional e satisfação com a vida (Anderson, Lau, Segal \& Bishop, 2007; Brown \& Kasser, 2005; Christopher, Charoensuk, Gilbert, Neary \& Pearce, 2009; McCraty, Atkinson, Lipsenthal \& Arguelles, 2003; Weinstein, Brown \& Ryan, 20009). Com o referido, foram acumuladas evidências acerca de incrementos significativos no coping, nas capacidades funcionais, na cognição, nos afetos e ainda no desempenho e no comportamento (Fernandes, 2010).

Os modelos de intervenção baseados em mindfulness postulam então dois componentes básicos (Bishop et al., 2004). O primeiro é a autorregulação da atenção para que esta seja mentida ao longo da experiência imediata, permitindo um maior reconhecimento dos eventos mentais que ocorrem no momento presente (Bishop et al., 2004). Um segundo componente envolve a adoção de uma orientação particular para as experiências de um momento presente, que é caraterizada por uma postura de curiosidade, aceitação e de curiosidade (Bishop et al., 2004). É de referri que existe um conjunto de crenças sobre a forma como se organizam, gerem e processam as informações necessárias para um estado de atenção plena. Por este motivo, geralmente, os programas de mindfulness têm um conjunto de regras relacionadas com os processos cognitivos e emocionais. Estas regras são fulcrais para a adoção e manutenção de uma postura de aceitação, curiosidade e compaixão, sendo que é defendido que tudo está relacionado com a consciência (Holas \& Jankowski, 2013). Assim, deve haver um distanciamento cognitivo onde os pensamentos são vistos, de forma objetiva, apenas como pensamentos e não como verdades absolutas (Baer, 2003).

A qualidade da atenção parece ter uma função autorreguladora na manutenção e na promoção da funcionalidade psicológica, fisiológica e comportamental (Fernandes, 2010). Assim, em alguns estudos, o treino de mindfulness é sugerido como sendo produtor de alterações no volume da massa 
cinzenta das estruturas cerebrais relacionadas com a atenção (Pagnoni \& Cekic, 2007), nos circuitos neuronais relacionados com o desenvolvimento de aptidões atencionais (Ivanovski \& Malhi, 2007).

Apesar de existirem alguns resultados inconclusivos acerca da consistência da eficácia da terapia e dos efeitos específicos destas terapias baseadas na atenção plena, díspares mecanismos têm sido sugeridos e explicam a redução dos sintomas e as mudanças comportamentais como estando associadas à aquisição de competências de mindfulness (Fernandes, 2010). É de realçar que alguns estudos apontam que estados mais elevados de atenção e aceitação poderão facilitar respostas mais adaptativas a situações de desempenho e reduzir a experiência de stresse emocional o que, consequentemente, leva a estados mentais mais positivos e a uma melhor qualidade de vida (Greeson, 2009). De um modo geral, a evolução das variáveis indicadoras de estados psicológicos negativos e/ou disfuncionais mostrou uma tendência para a redução do pré para o pós intervenção (Fernandes, 2010).

Atualmente, é um desafio cada vez maior adquirir e desenvolver capacidades de lidar com uma diversidade de perturbações mentais e/ou físicas ou mesmo com situações da vida diária geradoras de stresse. Assim, as intervenções baseadas no treino de aptidões de mindfulness são cada vez mais usadas e podem ser aplicadas a um conjunto diversos de populações acarretando resultados bastante positivos. De acordo com alguns estudos, estes tratamentos permitem ainda uma mudança na relação da perspetiva pessoal do sujeito com os seus processos internos (Neves, 2011).

\section{Prática de Mindfulness}

Como já foi referido, o mindfulness tem as suas raízes, essencialmente em práticas de meditação culturais sendo, contudo, cada vez mais utilizado em contextos médicos (Amishi, Krompinger \& Baime, 2007). A prática de mindfulness oferece uma perspetiva única acerca de questões críticas relativas aos pensamentos e à compreensão dos fundamentos cognitivos da natureza da experiência humana (Varela, Thompson \& Roach, 1991). Na filosofia budista, a prática da atenção plena no momento presente passa essencialmente por ser capaz de reconhecer como o sofrimento opera (Barker, 2010).

Neste seguimento, o mindfulness pretende então promover uma perspetiva flexível com o intuito de aumentar a habilidade de adaptação do ambiente de forma a fazer sentido para o sujeito. Esta capacidade de adaptação permite ao individuo ser mais autêntico, ver os benefícios em erros cometidos e entender que as avaliações e as comparações sociais são relativas e bastante subjetivas (Vandenberghe \& Assunção, 2009). Assim, estes fatores potenciam a aceitação de si próprio, um maior envolvimento no momento presente e ainda uma consciência mais alargada da relação entre as suas ações e as respetivas consequências (Langer \& Moldoveanu, 2000). 
Através do mindfulness pretende-se cultivar uma postura de abertura e de curiosidade trazendo isso para a vida quotidiana e não apenas para o momento em que de pratica (Barker, 2013). Assim, o praticante aprende a suspender o julgamento imediato de pensamentos e sensações e a não iniciar uma luta contra eles, sendo assim construída uma atitude de compaixão e de benevolência no que se refere a sentimentos, mesmo quando desagradáveis (Vandenberghe \& Assunção, 2009).

Sendo um processo de elaboração de novas formas de encarar os acontecimentos, os benefícios passam por uma maior sensibilidade para com o meio ambiente, uma maior abertura a novas informações, uma criação de categorias para a perceção das estruturas e ainda um reforço da consciência da existência de diferentes perspetivas na resolução de problemas (Langer \& Moldoveanu, 2000). Neste sentido, as transformações que ocorrem através do processo de mindfulness assemelham-se a um descentramento cognitivo, onde a ênfase é colocada na alteração do relacionamento com os pensamentos em vez de se tentar alterar a próprio conteúdo do pensamento. Neste sentido, existe um fortalecimento da capacidade de observação consciente da própria atividade mental, levando assim à mudança dos conceitos, imagens, sensações e crenças. Esta é descrita como sendo uma mudança do self como conteúdo para o self como contexto, sendo assim responsáveis pelas transformações facilitadoras de uma atenção plena (Segal, Williams \& Teasdale, 2002).

Apesar de existirem diversas formas de praticar mindfulness, em todas elas está subjacente que as diferenças individuais influenciam este processo (Holas \& Jankowski, 2013). Assim, existe uma clara influência e relação entre a qualidade do desempenho da tarefa e os esforços necessários para realizá-la (Eysenck, Derakshan, Santos \& Calvo, 2007). Neste seguimento, é de referir que diferentes sujeitos apresentam também díspares níveis de controlo cognitivo o que, consequentemente vai acarretar efeitos sobre a eficiência deste treino (Derryberry \& Reed, 2002). Assume-se assim que para a prática de mindfulness exista uma interação entre o treino da mente e uma predisposição genética, assim como circunstâncias ambientais favoráveis (Brown, Ryan \& Creswell, 2007). Deste modo, a prática da meditação potencia o desenvolvimento de habilidades para evocar estados de atenção o que permite a formação de elementos de promoção da atenção plena e consequente auto conhecimento consciente (Holas \& Jankowski, 2013). Neste sentido, com o aprofundamento gradual da prática do mindfulness emergem comportamentos interpessoais positivos, bem como cognições e emoções também positivas (Brown, Ryan \& Creswell, 2007).

Ao atingir o descentramento, a aceitação, a auto-compaixão e consequente diminuição do autofoco (Holas \& Jankowski, 2013), através do devido treino ao longo do tempo, presencia-se uma facilitação do processo de ativação mindfulness e uma crescente capacidade de permanecer nesse mesmo estado em atividades do quotidiano (Holas \& Jankowski, 2013; Sillifant, 2007). Para o referido, realça-se a importância de uma prática regulada e disciplinada de estar consciente de cada momento e estar totalmente alerta de forma a direcionar a atenção para o presente. Assim, a 
prática da atenção plena comtempla cada momento como um novo começo e uma nova oportunidade para voltar a começar (Fonseca, 2012).

Para além do referido, a prática de mindfulness pressupõe uma escuta ativa do próprio corpo e uma observação da corrente mental, oferecendo assim a sensação de que existe uma forma lúcida de contemplar os problemas. O mindfulness proporciona ainda ao sujeito conter-se e cultivar o não fazer, bem como a passar do modo de fazer ao modo de ser, alimentando a serenidade e a aceitação de si mesmo. Esta prática neutraliza o “piloto automático” da nossa mente, contribuindo assim para uma capacidade de eleição consciente. É ainda de realçar que esta não implica rejeitar pensamentos nem controlá-los, mas sim treinar o enfoque e a direção da atenção, proporcionando uma visão mais nítida dos problemas o que traz uma maior resolução perante a vida. Assim é crucial aprender a escutar o corpo de forma a melhorar a saúde e a qualidade de vida, sendo que, saber o que fazemos, enquanto o fazemos, constitui a essência da atenção plena (Fonseca, 2012).

Na prática do mindfulness, antes de mais, deve-se dirigir a atenção para o momento presente, para o que se está a viver (aqui e agora), adotando uma atitude de viver o que acontece, com compaixão, interesse, abertura e amabilidade, independentemente de advir da experiência um sentimento agradável ou desagradável, pressupondo assim, que as coisas sejam sentidas de forma direta e no imediato (Miró, 2007). A atenção plena implica um tipo de auto-observação que pode ser chamada de adaptativa, estando esta contraposta à auto-observação ruminadora ou não-adaptativa (Cebolla \& Miró, 2007), que leva a um funcionamento desajustado.

No decorrer do referido, é de suma importância entender como é que os indivíduos e as suas próprias emoções se relacionam com os seus pensamentos, pois é essa relação que vai determinar o comportamento em qualquer situação, inclusivé numa situação de conflito emocional. A prática de mindfulness pode ser uma grande ajuda para uma pessoa ter consciência das suas limitações e, consequentemente, evitar respostas impulsivas das quais derivam estados emocionais negativos (Ramos, Hermández \& Blanca, 20009). Uma atitude de observação é própria da atenção plena (Simón, V., 2001) e, assim sendo, o sujeito consciente de algo assegura o êxito nas suas ações. Pelo motivo referido, consegue perceber-se que através de exercícios de atenção plena sobre as próprias ações, atinge-se uma atenção madura o que, consequentemente, acarreta benefícios no desenvolvimento e na aprendizagem. (León, 2008).

Como já foi referido, cada sujeito é idiossincrático e, por este motivo, as diferenças individuais na qualidade de atenção plena também podem produzir diferenças no processo de mindfulness (Sillifant, 2007). Assim, existem algumas variáveis que interferem na personalidade e, por sua vez, neste processo, nomeadamente, o treino prévio da consciência, a predisposição genética e ainda as circunstâncias ambientais (Brown, Ryan \& Creswell, 2007). O sujeito deve aceitar que o pensamento é um pensamento e um sentimento é apenas um sentimento para ser capaz de começar a entender 
o processo de pensar e de sentir e não apenas o conteúdo desta atividade (Hayes, Strosahl \& Wilson, 1999). Um estado de consciência plena é então caraterizado por uma redução da associação entre o conhecimento básico e a metaconsciência, por um aumento da clareza da consciência base e ainda por uma redução das avaliações. Assim, o mindfulness leva a um estado de consciência plena e, raramente as pessoas conscientes experimentam pensamentos erróneos ou emergem em fantasias (Baer, Smith, Hopkins, Krietemeyer \& Toney, 2006). Neste sentido, pessoas conscientes experimentam sensações, emoções e pensamentos de uma forma mais clara (Feldman, Hayes, Kumar, Greeson \& Laurenceau, 2007).

A prática da atenção plena poderá levar a melhorias duradouras na eficácia das funções executivas (Lazar et al., 2005), pois, ao que parece, existem evidências acerca de alguma plasticidade neuronal o que proporciona um aumento da atividade no córtex pré-frontal (Schwartz \& Begley, 2002). 0 estado de mindful leva a uma clareza na perceção dos estados psicológicos e das emoções e ainda a uma abertura para a experiência e ao interesse por novas coisas (Fernandes, 2010). Assim e tendo em consideração que o praticamente de mindfulness tem uma maior consciência de si próprio e do mundo, a reatividade automática normal e a impulsividade transformam-se numa resposta mais refletida e levam o individuo a ter uma perspetiva mais alargada e mais compreensiva acerca de si próprio e do mundo (Ospina et al., 2007).

O estudo do mindfulness é algo que tem sido, cada vez mais, do interesse da psicologia, assumindo um papel preponderante no bem-estar psicológico e tem por base um conjunto de competências e/ou aptidões que são praticadas e apreendidas com o intuito de melhorar a saúde (Neves, 2011). Neste seguimento, o treino de mindfulness reduz o evitamento de conteúdos aversivos e, consequentemente, a ruminação mental e o aumento involuntário da atenção seletiva para tais conteúdos (Roemer \& Borkovec, 1994). Assim, o tratamento baseado em mindfulness permite uma mudança da relação da perspetiva pessoal do indivíduo com os seus processos internos, sendo que os pensamentos passam a ser vistos apenas como pensamentos e não significando verdades absolutas ou realidades do self, (Baer, 2003).

\section{Mensuração do constructo}

Como já tem sido referido, o mindfulness é um constructo multifacetado, heterogéneo e abrangente (Sternberg, 2000) e, por isso, o crescente interesse pelo mindfulness deu origem a várias definições e descrições deste (Sauer \& Baer, 2010 cit in, Gregório \& Pinto-Gouveia, 2013). Assim, procura-se a mensuração do constructo que tem vindo a ser operacionalizado, através da construção de vários instrumentos como o FFMQ (Questionário das Cinco Facetas de Mindfulness) e do FMI (Freiburg). Cada vez existe um maior interesse em correlacionar os níveis de consciência e de bem-estar 
através de programas que unam as práticas contemplativas. Assim, tem sido cada vez mais evidenciado que as capacidades metacognitivas desenvolvidas através do mindfulness contribuem para um redução significativa do afeto negativo e para o aumento da habilidade auto-regulativa (Atanes et al., 2012).

Neste sentido, as medidas de avaliação do mindfulness são indispensáveis para a compreensão da sua natureza, bem como dos seus componentes e mecanismos através dos quais exerce potenciais efeitos (Baer et al., 2006). Não obstante, a literatura empírica atesta amplamente a eficácia das intervenções baseadas no mindfulness (Gregório \& Pinto-Gouveia, 2011). Com vista a preencher esta lacuna, surgiu a necessidade de desenvolver outras medidas de mindfulness, nomeadamente: o Cognitive and Affective Mindfulness Scale-Revised (CMAS-R; Feldman, Hayes, Kumar, Greeson \& Lausenceau, 2007), o Freiburg Mindfulness Inventory (FMl; Buchheld, Grossman \& Walach, 2001; Walach, Buchheld, Grossman \& Schmidt, 2006), o Toronto Mindfulness Scale (TMS; Lau et al., 2006), o Kentucky Inventory of Mindfulness Skills (KIMS; Baer, Smith \& Allen, 2004), o Mindful Attention Awareness Scale (MAAS; Brown \& Ryan, 2003) e o Five Facet Mindfulness Questionnaire (FFMQ, Baer, Smith, Hopkins, Krietemeyer \& Toney, 2006; Baer et al., 2008).

Os questionários supra citos são de autorresposta e constituem uma oportunidade para investigar a natureza do mindfulness, assim como a sua relação com outros constructos psicológicos (Gregório \& Pinto-Gouveia, 2011). Isto resulta do facto destas medidas terem subjacente uma conceptualização do constructo de mindfulness, ou seja, são uma operacionalização que pretende capturar o mindfulness na sua essência (Baer et al., 2006).

\section{Mudanças no funcionamento sexual}

\section{Definição}

A sexualidade é definida pela Organização Mundial de Saúde (OMS) como sendo um aspeto central na vida dos sujeitos ao longo da sua vida. Por seu turno, a saúde sexual é descrita como sendo um processo contínuo de bem-estar físico, psicológico e sociocultural relacionado com a sexualidade. Esta engloba não só atividade sexual, como também papéis e identidades de género, orientação sexual, erotismo, prazer, intimidade e reprodução (Lerner, 2012; Mendonça, Silva, Arrudai, GarcíaZapata \& Amaral, 2012).

Neste sentido, a função sexual representa uma componente importante da saúde e da qualidade de vida (Mendonça, Silva, Arrudai, García-Zapata \& Amaral, 2012). De acordo com a Organização 
Mundial de Saúde (Collumbien, Busza, Cleland \& Campbell, 2012) a sexualidade é influenciada pela interação de diversos fatores tais como: biológicos, psicológicos, socioeconómicos, políticos, culturais, éticos, legais, históricos, religiosos e espirituais (Mendonça, Silva, Arrudai, García-Zapata \& Amaral, 2012; Dennerstein, Dudley \& Burger, 2001). Deste modo, é de realçar que a sexualidade é algo vivido e expresso em pensamentos, fantasias, crenças, desejos, atitudes, valores, comportamentos, práticas, papéis e relacionamentos (Mendonça, Silva, Arrudai, García-Zapata \& Amaral, 2012).

Para além dos referido, a sexualidade e/ou a função sexual parece ainda ser modulada por outros determinantes tais como a idade, o relacionamento com o parceiro, os níveis de ansiedade, a fadiga e a falta de intimidade. Por este motivo, é importante que a disfunção sexual seja desvinculada de qualquer alteração transitória do comportamento sexual (Abdo, 2008). Assim, o termo disfunção sexual refere-se a uma diversidade de condições clínicas, como o desejo sexual hipoativo, o transtorno de aversão sexual, o transtorno de excitação sexual, o transtorno do orgasmo e os transtornos dolorosos que são associados a uma acentuada diminuição da qualidade de vida e das relações interpessoais (Mendonça, Silva, Arrudai, García-Zapata \& Amaral, 2012).

O enfoque na sexualidade humana é amplo e abrangente uma vez que esta se manifesta em todas as fases do ciclo vital do ser humano e inclui diversas dimensões como psicológica, biológica, emocional, social, cultural e ainda espiritual (Vitiello \& Conceição, 1993; Lidório \& Tataren, s.d.). Assim, os fatores culturais são cruciais e contribuem para a manutenção das dificuldades, no sentido em que as crenças enraizadas se baseiam no desempenho sexual (Lidório \& Tataren, s.d.; Mendonça, Silva, Arrudai, García-Zapata \& Amaral, 2012).

Indo de encontro com o referido, alguns estudos apontam que os sujeitos, na sua grande maioria, têm grandes dificuldades em falar acerca dos seus problemas na área da sexualidade, tanto com o seu parceiro, como com um profissional de saúde (Buckstegge, Gouveia, Mafra \& Bobato, 2009). Assim, as principais dificuldades encontradas foram esta lacuna na comunicação, fazendo deste assunto tabu (Buckstegge, Gouveia, Mafra \& Bobato, 2009). Neste seguimento, o elevado grau de desconforto provocado pelas mudanças no funcionamento sexual é o principal motivo que leva os indivíduos com alterações no funcionamento sexual a procurem ajuda médica especializada (Lerner, 2012).

Existem inúmeros fatores que podem interferir de forma negativa na atividade sexual humana, dando lugar a mudanças no funcionamento sexual (Lucena \& Abdo, 2013). Tendo em conta que estas alteram a estrutura global do indivíduo e comprometem de modo significativo o bem-estar e a qualidade de vida (Buckstegge, Gouveia, Mafra \& Bobato, 2009), caraterizam-se por perturbações relacionadas com alterações psicofisiológicas nas fases do ciclo de resposta sexual (desejo, excitação, orgasmo e resolução) e com a dor associada à relação sexual, acarretando sofrimento 
psíquico e dificuldades de relacionamentos interpessoais (Lucena \& Abdo, 2013). Neste sentido, realça-se que a função sexual, sem qualquer disfunção e/ou mudança associada, é algo fulcral para a realização pessoal (Buckstegge, Gouveia, Mafra \& Bobato, 2009).

\section{Etiologia, prevalência e tratamento}

De acordo com diversos estudos epidemiológicos e clínicos, a prevalência de disfunções sexuais na população em geral é bastante elevada (Abdo, 2008; Lerner, 2012; McCarthy \& McCarthy, 2003). A sua etiologia varia e pode envolver componentes biológicos e psicológicos, incluindo condições clínicas gerais e neurológicas, medicações e ainda condições psicológicas (Lucena \& Abdo, 2013). Assim, as manifestações da sexualidade são uma dimensão com grande importância, em especial na dinâmica do relacionamento humano (Buckstegge, Gouveia, Mafra \& Bobato, 2009; Lerner, 2012; McCarthy \& McCarthy, 2003). Neste sentido torna-se fulcral estudar os métodos que auxiliam na resolução de problemas relacionados com a sexualidade (Buckstegge, Gouveia, Mafra \& Bobato, 2009; McCarthy \& McCarthy, 2003). Não obstante, a disfunção sexual é mais comum em pessoas com uma má saúde física e emocional e está associado a experiências negativas nas relações sexuais e no bem-estar geral (Baker \& Absenger, 2013).

Neste seguimento, as disfunções ou alterações no funcionamento sexual são cada vez mais tratadas com terapias medicamentosas e/ou com cirurgias (Baker \& Absenger, 2013). Apesar do referido, existem outros métodos e outras estratégias de intervenção fora do ambiente médico que auxiliam na reeducação sexual do adulto (Baker \& Absenger, 2013). Tendo em consideração que o bem-estar sexual é um contexto multidimensional, devem ser disponibilizadas abordagens centradas no paciente (Baker \& Absenger, 2013). Neste sendito, o crescente interesse por esta área tem levado a avanços científicos no que concerne a tratamentos médicos, tais como cirurgias, medicamentos e abordagens neurovasculares (Laumann, Paik \& Rosen, 1999).

\section{Caraterísticas de diagnóstico}

As disfunções sexuais têm um impacto negativo na qualidade de vida dos indivíduos (Keller, McGarvey \& Clayton, 2006) e podem ser resultado de uma doença ou um efeito colateral de tratamentos medicamentosos (Keller, McGarvey \& Clayton, 2006; Solursh et al., 2003). Como já foi referido anteriormente, as mudanças no funcionamento sexual, geralmente, são também associadas a um conjunto de outros fatores como questões físicas, psicológicas, acontecimentos traumáticos e outros efeitos colaterais de intervenções farmacológicas ou cirúrgicas (Solursh et al., 2003). Neste sentido, a Organização Mundial de Saúde (OMS) define a disfunção sexual como sendo aquela que 
não é causada por transtorno ou doença orgânica e pode subdividir-se em diversos tipos: ausência ou perda do desejo sexual, que pode levar à frigidez e/ou ao transtorno hipoativo do desejo sexual; aversão sexual e ausência de prazer sexual caraterizados pela anedonia sexual; falha na resposta genital retratada através da disfunção de ereção no homem; disfunção orgásmica que pode gerar anorgasmia psicogénica e/ou inibição do orgasmo; ejaculação precoce; vaginismo não orgânico; dispareunia não orgânica; apetite sexual excessivo que pode dividir-se em ninfomania e satiríase; outras disfunções sexuais que não sejam devidas a transtorno ou a doenças orgânicas que consiste em dismenorreia psicogénica; disfunção sexual devido a transtorno ou doença orgânica não especificada (Buckstegge, Gouveia, Mafra \& Bobato, 2009).

Assim, é considerada uma disfunção sexual quando há menos frequência, intensidade e qualidade do funcionamento sexual (Abdo, 2008). Para esta ser diagnosticada, geralmente, são feitos exames de dosagens hormonais complementares e verificam-se ainda as condições clínicas gerais. Para além da queixa e da insatisfação deve ainda ser tido em consideração um mínimo de seis meses de sintomatologia para a caraterização e diagnóstico das disfunções sexuais. Para além disso, durante a anamnese, é de relevante importância investigar também as condições sexuais e de saúde geral do(a) parceiro(a), de forma a afastar possíveis equívocos de interpretação (Lucena \& Abdo, 2013).

Para designar o início da dificuldade são usados alguns subtipos, pois para alguns indivíduos o momento em que se inicía pode levar a diferentes etiologias e intervenções. Assim, o subtipo "Ao longo da vida" diz respeito a uma dificuldade sexual que esteve presente desde as primeiras atividades sexuais. Por sua vez o subtipo "Adquirido" refere-se a perturbações sexuais que se desenvolvem após um período de funcionamento sexual dito normal. Por outro lado, existe ainda o subtipo "Generalizado" que sugere que as dificuldades sexuais não se limitam a determinados tipos de estimulação, situações ou parceiros. Enquanto o subtipo "Situacional" diz respeito a dificuldades sexuais que apenas se verificam com determinados tipos de estimulação, situações ou parceiros (American Psychiatric Association, 2013).

Para além dos subtipos referidos devem ter sidos em consideração outras fatores que podem ser revelantes para a etiologia e/ou tratamento e que podem ser diferentes entre indivíduos. Dentro destes fatores encontra-se: fatores do parceiro (por exemplo, problemas sexuais do parceiro, estado de saúde do parceiro), fatores da relação (por exemplo, falta de comunicação e discrepâncias quanto ao desejo de atividade sexual), fatores de vulnerabilidade individual (por exemplo, baixa imagem corporal, história de abuso sexual ou emocional), comorbilidade psiquiátrica (por exemplo, depressão ou ansiedade), fatores de stresse (por exemplo, desemprego ou luto), fatores culturais ou religiosos (por exemplo, inibições relacionadas com proibições contra a atividade sexual ou contra o prazer; atitudes face à sexualidade) e fatores médicos relevantes para o prognóstico, curso ou tratamento (American Psychiatric Association, 2013). 
É de realçar que a resposta sexual se baseia em requisitos biológicos, sendo experienciada num contexto intrapessoal, interpessoal e cultural. Para se fazer o diagnóstico de qualquer alteração no funcionamento sexual deve ainda ter-se em consideração os fatores culturais que podem influenciar as expetativas ou acarretar proibições acerca da experiência do prazer sexual. Outro factor a ter em conta é também o envelhecimento que pode estar relacionado com uma diminuição normativa da resposta sexual. Deste modo, a (dis)função sexual engloba uma complexa interação entre fatores biológicos, socioculturais e psicológicos (American Psychiatric Association, 2013).

Neste seguimento, é de referir que as disfunções sexuais incluem: ejaculação retardada, disfunção erétil, perturbação do orgasmo feminino, perturbação do interesse/excitação sexual feminino, perturbação de dor genitopélvica/penetração, perturbação do desejo sexual hipoativo masculino, ejaculação prematura (precoce), disfunção sexual induzida por substância/medicamento, disfunções sexuais com outra especificação e disfunções sexuais não especificadas (American Psychiatric Association, 2013; Lucena \& Abdo, 2013)

A ejaculação retardada carateriza-se por um atraso marcado ou pela incapacidade de atingir a ejaculação. 0 homem, geralmente, refere dificuldade e/ou incapacidade para ejacular, mesmo na presença de estimulação sexual adequada e mesmo tendo o desejo de ejacular. Na maior parte dos casos o diagnóstico é feito através do autorrelato do indivíduo. É ainda de referir que os sintomas devem estar presentes durante pelo menos seis meses e devem causar mal-estar clinicamente significativo ao sujeito. Esta disfunção não é melhor explicada por uma perturbação mental não sexual nem é uma consequência de dificuldades relacionais graves nem de outros fatores de stresse significativos e não é atribuível aos efeitos de uma substância/medicamento ou de outra condição médica. No diagnóstico deve ainda especificar-se se é uma perturbação ao longo da vida ou adquirida, generalizada ou situacional e se é ligeira, moderada ou grave. A prevalência desta alteração no funcionamento sexual não é clara, sendo que é a queixa sexual masculina menos comum, uma vez que, apenas menos de $1 \%$ dos homens, refere ter problemas em atingir a ejaculação que persista por mais de seis meses (American Psychiatric Association, 2013).

A disfunção erétil carateriza-se pela incapacidade repetida de atingir ou manter as ereções durante as atividades sexuais com o parceiro e ainda se denota por uma diminuição marcada pela rigidez da ereção. Deve ser feita uma cuidadosa análise na história sexual do sujeito para assegurar que este problema esteve presente durante um período de pelo menos seis meses e que ocorre na maioria das atividades sexuais. A maioria dos homens com esta disfunção apresentam uma baixa autoestima, baixa autoconfiança e uma diminuída sensação de masculinidade e pode ainda ocorrer medo e/ou evitamento de manter contatos sexuais futuros. Esta disfunção não é melhor explicada por uma perturbação mental não sexual nem é uma consequência de dificuldades relacionais graves nem de outros fatores de stresse significativos e não é atribuível aos efeitos de uma substância/medicamento ou de outra condição médica. No diagnóstico deve ainda especificar-se se 
é uma perturbação ao longo da vida ou adquirida, generalizada ou situacional e se é ligeira, moderada ou grave. No que concerne à prevalência desta disfunção existe um aumento significativo com o aumento da idade, em particular depois dos 50 anos. Cerca de 13\%-21\% dos homens entre os 40 e os 80 anos apresentam queixas de problemas ocasionais com as ereções. Cerca de $2 \%$ dos homens com idades inferiores a 40-50 anos queixam-se de problemas frequentes com ereções, enquanto $40 \%-50 \%$ dos homens com mais de $60-70$ anos podem ter problemas significativos com ereções. É de referir também que $20 \%$ dos homens referem ter medo de ter problemas de ereção na primeira experiência sexual, mas apenas aproximadamente $8 \%$ experienciam problemas de ereção que impediram a penetração na primeira atividade sexual (American Psychiatric Association, 2013).

A perturbação do orgasmo feminino carateriza-se pela dificuldade em experienciar o orgasmo e/ou marcada diminuição da intensidade das sensações orgásmicas. Para que este diagnóstico seja confirmado, os sintomas devem estar presentes em todas ou quase todas (75\%-100\%) as atividades sexuais. Para além do referido, os sintomas devem verificar-se durante pelo menos seis meses e provocarem mal-estar clinicamente significativo. Esta disfunção não é melhor explicada por uma perturbação mental não sexual nem é uma consequência de dificuldades relacionais graves nem de outros fatores de stresse significativos e não é atribuível aos efeitos de uma substância/medicamento ou de outra condição médica. No diagnóstico deve ainda especificar-se se é uma perturbação ao longo da vida ou adquirida, generalizada ou situacional e se é ligeira, moderada ou grave. A prevalência nas perturbações do orgasmo feminino varia entre os $10 \%$ e os $42 \%$, sendo que depende de múltiplos fatores, tais como a idade, a cultura, a duração e a gravidade dos sintomas (American Psychiatric Association, 2013).

A perturbação do interesse/excitação sexual feminino carateriza-se pela ausência e/ou redução do interesse na atividade sexual, pela ausência e/ou redução de pensamento sexuais/eróticos ou de fantasias, pela ausência e/ou redução da iniciativa para a atividade sexual e não recetividade às tentativas do parceiro para iniciar a atividade sexual, pela ausência e/ou redução da excitação/prazer sexual durante a atividade sexual em todos ou quase todos os encontros sexuais, pela ausência e/ou redução do interesse/excitação sexual na presenta de quaisquer estímulos sexuais internos ou externos e pela ausência e/ou redução das sensações genitais ou não genitais durante a atividade sexual em quase todos ou todos os encontros sexuais. Os referidos sintomas devem causar mal-estar clinicamente significativo ao sujeito e devem estar presentes durante um período mínimo de seis meses. Esta disfunção não é melhor explicada por uma perturbação mental não sexual nem é uma consequência de dificuldades relacionais graves nem de outros fatores de stresse significativos e não é atribuível aos efeitos de uma substância/medicamento ou de outra condição médica. No diagnóstico deve ainda especificar-se se é uma perturbação ao longo da vida ou adquirida, generalizada ou situacional e se é ligeira, moderada ou grave. A prevalência da referida perturbação referida ainda é desconhecida e pode variar de forma bastante significativa 
em relação à idade, ao contexto cultural, à duração dos sintomas e à presença de mal-estar (American Psychiatric Association, 2013).

A perturbação de dor genitopélvica/penetração carateriza-se pela dificuldade em ter relações sexuais, pela dor genitopélvica, pelo medo da dor ou da penetração vaginal e pela tensão dos músculos do pavimento pélvico. Os referidos sintomas devem causar mal-estar clinicamente significativo ao sujeito e devem estar presentes durante um período mínimo de seis meses. Esta disfunção não é melhor explicada por uma perturbação mental não sexual nem é uma consequência de dificuldades relacionais graves nem de outros fatores de stresse significativos e não é atribuível aos efeitos de uma substância/medicamento ou de outra condição médica. No diagnóstico deve ainda especificar-se se é uma perturbação ao longo da vida ou adquirida, generalizada ou situacional e se é ligeira, moderada ou grave. A prevalência desta disfunção é ainda desconhecida, no entanto sabe-se que cerca de $15 \%$ das mulheres da América do Norte referem dor recorrente durante as relações sexuais (American Psychiatric Association, 2013).

A perturbação do desejo sexual hipoativo masculino carateriza-se por uma recorrente e persistente diminuição e/ou ausência de pensamento ou fantasias sexuais/eróticos e de desejo de atividade sexual. Para que este diagnóstico seja feito, devem ser tidos em consideração diversos fatores que afetam o funcionamento sexual como a idade e o contexto de vida geral e sociocultural do sujeito. Os referidos sintomas devem causar mal-estar clinicamente significativo ao sujeito e devem estar presentes durante um período mínimo de seis meses. Esta disfunção não é melhor explicada por uma perturbação mental não sexual nem é uma consequência de dificuldades relacionais graves nem de outros fatores de stresse significativos e não é atribuível aos efeitos de uma substância/medicamento ou de outra condição médica. No diagnóstico deve ainda especificar-se se é uma perturbação ao longo da vida ou adquirida, generalizada ou situacional e se é ligeira, moderada ou grave. A prevalência desta disfunção é diferente consoante o país e origem e o método de avaliação. Apesar do referido, sabe-se que cerca de $6 \%$ dos homens com idades entre os 18 e os 24 anos e $41 \%$ dos homens mais velhos que se encontram entre os 67 e os 74 anos têm problemas relacionados com o desejo sexual (American Psychiatric Association, 2013).

A ejaculação prematura (precoce) carateriza-se por um padrão recorrente e persistente de ejaculação que ocorre durante a atividade sexual com o parceiro até aproximadamente um minuto após a penetração vaginal e antes que seja desejada pelo indivíduo. Os sintomas supra citos devem causar mal-estar clinicamente significativo ao sujeito e devem estar presentes durante um período mínimo de seis meses. Esta disfunção não é melhor explicada por uma perturbação mental não sexual nem é uma consequência de dificuldades relacionais graves nem de outros fatores de stresse significativos e não é atribuível aos efeitos de uma substância/medicamento ou de outra condição médica. No diagnóstico deve ainda especificar-se se é uma perturbação ao longo da vida ou adquirida, generalizada ou situacional e se é ligeira, moderada ou grave. A presente disfunção 
sexual ocorre entre $1 \%$ a $3 \%$ dos homens, sendo que esta prevalência poderá aumentar com a idade (American Psychiatric Association, 2013).

Podemos ainda encontrar uma disfunção sexual induzida por substâncias/medicamento e, no quadro clínico predomina uma disfunção sexual clinicamente significativa. Através de história de vida, de um exame físico ou de achados laboratoriais verificam-se evidências de que os sintomas de disfunção sexual se desenvolveram durante ou pouco tempo após a intoxicação ou abstinência de um substância ou após a exposição a um medicamente. A perturbação não decorre exclusivamente no decurso de um delirium e causa mal-estar clinicamente significativo no sujeito. No diagnóstico desta perturbação sexual deve ser especificado se esta tem início durante a intoxicação, durante a abstinência ou após o uso do medicamente e ainda se é ligeira, moderada ou grave. A prevalência e incidência da presente perturbação sexual não são claras, o que é justificado pela subnotificação de efeitos secundários sexuais desencadeada também por diferentes tratamentos (American Psychiatric Association, 2013).

O diagnóstico da disfunção sexual com outra especificação é feito quando existem sintomas caraterísticos de disfunção sexual que causam mal-estar clinicamente significativo ao indivíduo, mas que não cumprem os critérios de diagnóstico completos de nenhuma das perturbações da classe diagnóstica das disfunções sexuais. Nesta perturbação o clínico opta por comunicar qual a razão (por exemplo: aversão sexual) para esta não cumprir os critérios de nenhuma disfunção sexual específica (American Psychiatric Association, 2013).

Por fim, a disfunção sexual não especificada aplica-se a apresentações nas quais os sintomas característicos de disfunção sexual que causam mal-estar clinicamente significativo ao sujeito predominam, mas não cumprem os critérios completos de nenhuma das perturbações da classe diagnosticada das disfunções sexuais. Nesta categoria o clínico opta por não especificar a razão específica pela qual os critérios não são preenchidos para uma disfunção sexual. Para além do referido, este diagnóstico é feito quando não existe informação suficiente para ser feito um diagnóstico específico (American Psychiatric Association, 2013).

\section{Ciclos de resposta sexual}

Não poderia deixar de ser referido que também o ciclo de resposta sexual é influenciado de forma negativa por diversos fatores psicológicos, nomeadamente a ansiedade, a baixa autoestima, os distúrbios na perceção da imagem corporal, o medo de rejeição, a ansiedade de desempenho sexual, as experiências sexuais traumáticas, a história de abuso e ainda a qualidade da relação. Para além do referido, este ciclo pode também ser influenciado negativamente por outros fatores, 
como o desequilíbrio hormonal, vascular, fisiológico, condições médicas, musculares e ainda por cirurgias ou medicamentos (Mendonça, Silva, Arrudai, García-Zapata \& Amaral, 2012).

As disfunções sexuais podem ocorrer em qualquer um dos ciclos de resposta sexual, contudo, são mais frequentes nas três primeiras fases do ciclo e é comum um indivíduo apresentar mudanças no funcionamento sexual em mais do que uma fase do ciclo de resposta (Lucena \& Abdo, 2013). A excitação sexual e a resposta sexual nos seres humanos são influenciadas por diversos fatores tais como pela capacidade do cérebro para criar imagens e fantasias, pelas emoções, pelos processos sensoriais, pelo nível de intimidade entre as duas pessoas, entre outros (Crooks \& Baur, 2008). Neste sentido, vários fatores estão envolvidos e influenciam a excitação sexual, desde os psicossociais, fisiológicos, psicológicos até aos culturais. É esta interação entre os diversos fatores concomitantemente com as caraterísticas idiossincráticas de cada sujeito que interferem de forma significativa na função sexual do sujeito (Crooks \& Baur, 2008).

A resposta sexual humana é um processo físico, emocional e mental que é altamente individual. Não obstante, há uma série de alterações físicas comuns que permitem delinear alguns padrões gerais do ciclo de resposta sexual, sendo que existe uma panóplia bastante diversificada de padrões (Crooks \& Baur, 2008). Neste sentido, Masters e Johnson (1966) criaram um modelo que incluía quatro fases nos padrões de resposta sexual: excitação, plateau, orgasmo e resolução (Crooks \& Baur, 2008).

Neste seguimento, no que concerne à resposta sexual feminina, a primeira fase proposta por Masters e Johnson (1966) é a excitação que se traduz no aumento da pressão sanguínea e do batimento cardíaco. Através da vasoconstrição acumula-se sangue nas veias, particularmente na vagina e na pélvis, provocando assim a alteração da coloração dos tecidos vaginais. À medida que o sangue se acumula a mulher tem uma sensação de calor e de inchaço, normalmente acompanhada de secreção vaginal. Esta secreção, que é alcalina, permitirá uma entrada mais confortável do pénis e altera-se ao longo da resposta sexual. Existem diversas alterações no útero, nos pequenos e nos grandes lábios, na cabeça do clitóris e estas mudanças são diferentes de mulher para mulher e podem ser mais notórias na masturbação do que no coito (Crooks \& Baur, 2008).

Segue-se a fase do Plateau na resposta sexual feminina. Esta é a fase preparatória para o orgasmo e é uma fase de tensão sexual e desejo. Com a continuação da estimulação erótica as alterações físicas e psicológicas prosseguem, nomeadamente a sensação de aumento do prazer. Um dos aspetos centrais desta fase é a ligeira retração do clitóris. Para além do referido, a mudança fisiológica mais proeminente ocorre no terceiro terço exterior da vagina o que provoca um estreitamento significativo da entrada da vagina o que, numa eventual penetração, faz a adaptação do pénis e aumenta a estimulação tátil e consequente aumento do prazer para ambos. A auréola do mamilo ainda incha substancialmente durante a presente fase e ao mesmo tempo ocorre o fluxo sanguíneo de forma mais intensiva, provocando tensão muscular (Crooks \& Baur, 2008). 
A fase do orgasmo é a terceira fase da resposta sexual feminina e traduz-se na libertação rápida da tensão acumulada na fase anterior. Neste sentido, é uma sensação de prazer que focaliza toda a atenção do sujeito. Aqui acontece uma perda rápida da vasoconstrição na abertura vaginal, resultando na perda da plataforma orgásmica e da musculatura que rodeia o ânus e a uretra. As contrações vaginais acontecem de forma rítmica e, em alguns casos, de forma prolongada e separadas por um segundo no início do orgasmo. À medida que estas contrações continuam, ficam mais espaçadas e menos intensas. É ainda de referir que, durante a fase do orgasmo, também se verificam contrações no útero, mas de forma menos regular na intensidade e na duração e acontecem ainda outros movimentos involuntários (Crooks \& Baur, 2008).

Por fim, a última fase da resposta sexual feminina é a fase da resolução onde o corpo da mulher regressa ao estado de pré-excitação. Nesta fase o clitóris retoma a sua posição normal e o colo do útero ganha amplitude, as mamas regressam à posição inicial e o mamilo e a auréola desincham. É de referir que esta fase acontece mais rapidamente nas mulheres mais velhas, quando comparadas com as mais novas. Nesta fase, a maioria das mulheres refere que apreciam ser abraçadas, afagadas e acariciadas, pois o coito agora ganha uma textura mais emocional (Crooks \& Baur, 2008).

No que concerne à resposta sexual masculina e tendo em consideração o mesmo modelo de Masters e Johnson (1966) a primeira fase corresponde igualmente à excitação. Neste período a ereção ocorre a partir da vasoconstrição da área pélvica, produzindo a elevação do pénis e a uma retração dos testículos. 0 escroto é trazido para mais perto do corpo e a pele fica mais enrugada e dura, provocando assim a elevação dos testículos, A duração da referida ereção varia significativamente de homem para homem, sendo que com o aumento da idade esta é mais prolongada. É também muito variável o estímulo que provoca a ereção, podendo implicar estímulos auditivos, visuais, táteis, fantasiosos, entre outros. Analogamente ao que acontece com as mulheres, os mamilos do homem também podem ficar eretos, ocorrem contrações musculares generalizadas e alterações no batimento cardíaco bem como na respiração (Crooks \& Baur, 2008).

Na segunda fase de resposta sexual masculina - Fase do Plateau - o pénis aumenta ligeiramente de diâmetro, de forma mais óbvia em torno da glande. Devido à vasoconstrição, o pénis também pode mudar de cor, torando-se mais escuro. Durante esta fase os testículos aproximam-se do corpo, de modo a que possa ser expelido com mais força na ejaculação. Os testículos também aumentam de tamanho nesta fase devido à vasoconstrição e aqui o homem começa a segregar líquido pré-seminal. É ainda de referir que a tensão corporal é generalizada e a respiração, o batimento cardíaco e a tensão arterial aumentam (Crooks \& Baur, 2008).

A fase do orgasmo é a terceira fase da resposta sexual masculina e esta envolve contrações musculares da genitália e da pélvis. Nesta fase os músculos que envolvem a uretra e os corpos cavernosos contraem-se de modo a expulsar o sémen de forma intervalada, começando com 
intervalos de menos de um segundo e tornam-se ligeiramente mais longas após as primeiras emissões. É de referir que estas durações, tal como nas mulheres, variam de indivíduo para indivíduo. $\mathrm{O}$ orgasmo é ainda acompanhado de espasmos involuntários e de algumas verbalizações. A tensão muscular durante a emissão e expulsão dos fluidos seminais é intensa e fazem com que o batimento cardíaco e a tensão arterial aumentem (Crooks \& Baur, 2008).

Por fim, temos a fase de resolução que se traduz no regresso a uma fase de pré excitação e envolve a diminuição e amolecimento do pénis (detumescência) que ocorre em duas fases. A primeira é logo a seguir à ejaculação e o pénis diminui cerca de $50 \%$ do seu tamanho enquanto ereto e, na segunda fase, o pénis diminui até ao seu tamanho normal. Após a ejaculação e o orgasmo, o homem entra no período refratário que significa não estar responsivo, ou seja, nesta fase, a estimulação erótica não voltará a excitar o homem e este não poderá ter de imediato outra ereção. É ainda de referir que com o aumento da idade, maior será também o período refratário. Nesta fase de resolução os testículos regressam ao seu tamanho de pré-excitação e baixam à sua posição normal no escroto. Por fim, a pressão arterial e a respiração voltam à sua normalidade e o fluxo sanguíneo dissipa-se (Crooks \& Baur, 2008).

É ainda de realçar que o transtorno de qualquer uma das fases de resposta sexual supracitas traduzse no surgimento de disfunções/mudanças sexuais (Ferreira, Sousa \& Amorim, 2007). Assim, conforme as pessoas vão envelhecendo, estas podem notar algumas alterações nos padrões de excitação e de resposta sexual. Neste sentido, de forma geral, todas as fases do ciclo de resposta continuam a existir em indivíduos mais velhos, contudo, pode ocorrer alguma diminuição de intensidade e/ou duração da resposta. (Crooks \& Baur, 2008).

\section{Bem-estar sexual subjetivo}

A sexualidade é uma parte integrante da vida humana e promove a intimidade, a ligação e o prazer (Diamond \& Huebner, 2012; Buckstegge, Gouveia, Mafra \& Bobato, 2009; Lerner, 2012; McCarthy \& Wald, 2013). Esta acaba por ser responsável por um conjunto de necessidades pessoais e sociais e, por isso, a saúde e o bem-estar sexual são ligadas, de forma indissociável à saúde física e mental (Satcher, 2001; Frohlich \& Meston, 2002), bem como aos mecanismos de funcionamento sexual, que assentam nos padrões de resposta sexual para os homens e para as mulheres (desejo, excitação, orgasmo e resolução) (Lucena \& Abdo, 2013), sendo também variáveis importantes na autoavaliação da satisfação com o relacionamento e bem-estar geral (Buckstegge, Gouveia, Mafra \& Bobato, 2009). Isto permite, portanto, entender que os problemas sexuais podem ser uma fonte de sofrimento e insatisfação (Mendonça, Silva, Arrudai, García-Zapata \& Amaral, 2012). 
Neste seguimento e associado à sexualidade é crucial referir aqui o bem estar-sexual subjetivo foco também do presente trabalho. Assim, o bem-estar sexual subjetivo refere-se à perceção da qualidade da própria sexualidade, à sua vida sexual e às suas relações sexuais (Edwards \& Bryning, 2013). Ao debruçar-nos sobre este construto, examinamos a satisfação sexual em diversos domínios, nomeadamente satisfação com aspetos físicos e emocionais das relações, satisfação com o funcionamento sexual e ainda a importância da sexualidade da vida em geral (Laumann, Paik \& Rosen, 1999). Para além do referido, o comportamento sexual está ainda altamente correlacionado com uma variedade de outros fenómenos, desde o biológico, ao psicológico e social, o que acarreta consequências diretas para a saúde e para o bem-estar (Diamond \& Huebner, 2012; Rosen \& Bachmann, 2008; Davison, Bell, lachina, Holden \& Davis, 2009; Holmberg, Blair \& Phillips, 2010).

Neste seguimento, o conceito de bem-estar sexual subjetivo tem sido definido como uma avaliação cognitiva e emocional da sexualidade de um sujeito (Traeen \& Schaller, 2010; Oberg, Fugl-Meyer \& Fugl-Meyer, 2002), traduzindo-se na perceção que o sujeito tem da sua satisfação física e emocional nos vários domínios da sexualidade (Edward, 2006) e da saúde, retratando por isso um termo mais amplo do que a satisfação sexual (Traeen \& Schaller, 2010). Apesar do bem-estar sexual subjetivo estar bastante relacionado com a satisfação sexual, há sempre mais estudos que se baseiam apenas na satisfação sexual e menos no bem-estar sexual subjetivo (Traeen \& Schaller, 2010).

Como já foi referido, o bem-estar sexual subjetivo está também intimamente ligado com as emoções e, neste sentido, os sujeitos que estão emocionalmente mais equilibrados e mais felizes, revelam também um maior nível de bem-estar sexual, o que está em conformidade com outros estudos nórdicos (Traeen \& Schaller, 2010). Neste sentido, Rosen e Bachman (2008) alertam para o possível papel da psicologia positiva na área da sexualidade humana e na contribuição para o aumento da satisfação sexual e/ou relacional o que consequentemente, aumenta o bem-estar físico e emocional (Balon, 2008). Assim, os problemas negativos associados a alterações no funcionamento sexual parecem intervir de forma significativa na perspetiva que a pessoa tem de si própria e isso pode levar a atos sexuais menos satisfatórios uma vez que há uma diminuição de autoestima (Traeen \& Schaller, 2010). Desta forma, pode concluir-se que o bem-estar sexual subjetivo está correlacionado com a perceção que o sujeito tem de si próprio (Traeen \& Schaller, 2010). Sabe-se ainda que um clima geral lúdico e de positividade entre o casal, bem como a capacidade de resposta num relacionamento, facilitam as respostas adaptativas à vida quotidiana stressora, sendo mais fácil encarar períodos de tensão e promover o contínuo desenvolvimento psicossocial, interpessoal de uma forma positiva, o que consequentemente leva a um aumento do bem-estar sexual subjetivo. (Gable \& La Guardia, 2007; Gable, Reis, Impett \& Asher, 2004; Gottman, 1994; Gottman \& Levenson, 2000).

A larga maioria das escalas de bem-estar sexual não incluem qualquer medida que faça referência ao bem-estar sexual subjetivo (Hooghe, 2012). Uma cez que a sexualidade é parte integrante e 
indissociável do bem-estar humano, o bem-estar sexual subjetivo deve ser incluído nas medições de bem-estar que são aplicadas às populações de forma bastante comum (Hooghe, 2012). Apesar da crucial importância da sexualidade para o bem-estar de qualquer indivíduo (Diamond \& Huebner, 2012) e da crescente atenção para o desenvolvimento de indicadores de bem-estar, nota-se que a sexualidade associada a este é quase nula na literatura (Hooghe, 2012). Tendo em conta que a sexualidade e o bem-estar sexual são elementos essenciais das capacidades humanas e também da felicidade humana, a falta de investigação nesta área é uma lacuna que deve ser colmatada (Nussbaum \& Sen, 1993; Diamond \& Huebner, 2012).

\section{Mindfulness, mudanças no funcionamento sexual e bem-estar sexual subjetivo}

Nas últimas décadas Jon Kabat-Zinn, dedicou-se ao estudo do mindfulness, tentando trazer esta prática para o Ocidente e associando-a ao caráter médico e psiquiátrico. Neste sentido, o mindfulness tem vindo a ser aplicado a uma panóplia diversificada de populações com doenças psiquiátricas, tais como como transtorno de personalidade borderline, depressão, abuso de substâncias, transtornos alimentares, transtornos de ansiedade, psicoses, problemas de comportamento infantil, entre outros (Lazaridou \& Kalogianni, 2013; Brotto \& Heiman, 2007). Atualmente, o mindfulness representa no campo da medicina comportamental e da psicologia um recurso terapêutico adequado (Justo, Manãs \& Martínez, 2010).

No campo da sexualidade, a essência do mindfulness traduz-se na consciência cognitiva, comportamental, emocional e numa postura de aceitação e foco no aqui e no agora acerca das sensações sexuais (McCarthy \& Wald, 2013). Deste modo, a atenção plena parece levar a um ganho de tempo, energia, coragem, determinação e disciplina (Goldmeier, 2013). Claro está que existem diferenças inter e intrapessoais na propensão para estar atento e para manter a atenção no momento (Brown \& Ryan, 2003), contudo, esta capacidade de auto-regulação da atenção pode ser desenvolvida e aperfeiçoada através da prática mediativa. Assim, a meditação é vista como uma auto-regulação intencional da atenção no momento presente (Kabat-Zinn, 1982) e pode ser aprendida através de uma panóplia de exercícios que encorajam o sujeito a prestar atenção a experiências internas e a aspetos do ambiente (Baer, 2003). Neste sentido, a aprendizagem e a prática da atenção plena pode despoletar tolerância a estados emocionais negativos e a mudanças nos padrões de pensamento ou até mesmo nas próprias atitudes perante os pensamentos e, deste modo, aumenta a capacidade para os gerir de forma mais efetiva (Baer, 2003). 
Num estado de atenção plena nota-se uma redução dos estilos disfuncionais de coping e são promovidos estilos adaptativos diminuindo assim o nível de stresse e a ativação psicofisiológica (Garland, 2007). Denota-se que o referido acorre através de um conjunto de vias psicofisiológicas e comportamentais que levam a mudanças cognitivas, emocionais, biológicas e comportamentais (Fernandes, 2010). Neste sentido, são estas que atuam e comandam a regulação da atenção e do comportamento e, desta forma, a atenção plena parece prevenir disfuncionalidades relacionadas com as mais diversificadas patologias (Coffey \& Hartman, 2008).

Alguns elementos como a atenção, a curiosidade, a aceitação e a avaliação sem julgamento enfatizam o papel do processamento enviesado da informação (Fernandes, 2010). Neste sentido, o desenvolvimento da atenção e da aceitação sem julgamento parecem promover um melhor desempenho (Gardner \& Moore, 2004). A prática de mindfulness oferece uma possibilidade de libertação da tirania dos pensamentos e, deste modo, o sujeito não se envolve na atividade mental em si, mas observa o fluxo natural da atividade da mente de forma a conseguir um estado de calma mental e de consciência plena. Neste sentido, o treino de auto-direcionamento da atenção plena pode resultar na manutenção da exposição a estímulos adversos, como sensações, pensamentos e emoções, o que poderá levar a uma dessensibilização das respostas condicionadas e de comportamentos de evitamento (Fernandes, 2010).

Como referido anteriormente, a prática da atenção plena promove uma relação de aceitação com experiências emocionais, cognitivas e físicas de medo e de preocupação. Assim, o foco da atenção, a aceitação e a auto-compaixão em relação às próprias preocupações diárias, facilita, de forma saudável, um melhor relacionamento com as experiências adversas (Fernandes, 2010). Tal facto deve-se essencialmente à atitude de curiosidade, à abertura e à aceitação com o próprio, com os outros e com o mundo (Greeson \& Brantley, 2009).

Alguns investigadores e técnicos de saúde mental concordam que a prática de mindfulness é benéfica em indivíduos que sofrem de vários problemas e de perturbações psicológicas (Baer, 2003). Outros autores defendem também que o mindfulness, como terapia individual, é benéfico também para o tratamento de problemas conjugais (Neves, 2011). Assim, o mindfulness tem sido incorporado na psicoterapia, ou seja, em protocolos de tratamento de várias perturbações psicológicas com o intuito de intervir em processos mentais que contribuem para a perturbação mental e para o comportamento mal adaptativo (Bishop, et al., 2004) de forma a promover o bem-estar e a redução da sintomatologia psicopatológica (Neves, 2011).

Quando aplicado na psicoterapia, o mindfulness por ser visto como uma nova forma de abordagem de situações que visa a diminuição da reatividade emocional de resposta e o treino de uma nova resposta condicionada (Neves, 2011). Nesta linha, o mindfulness associado a protocolos de tratamento pretende treinar uma nova resposta condicionada, isto é, uma resposta mais consciente 
às experiências internas negativas sem fazer julgamentos e com uma postura de aceitação (Bishop, 2002 cit in Cardaciotto, 2005; Christensen \& Jacobson, 2000 cit in Germer, 2005).

No decorrer do referido, pode dizer-se que o próprio processo de mindfulness é uma estratégia de coping adaptativa, uma vez que se mostra ser eficaz no controle e redução de afetos negativos (Arch \& Craske, 2006; Broderick, 2005). É ainda de referir que o mindfulness influencia a capacidade de alerta e atenção sustentada (Chambres, Lo \& Allen, 2008; Jha, Krompinger \& Baime, 2007; Tang et al., 2007), a melhoria no desempenho da atenção, a melhoria na memória de trabalho (Chambres, Lo \& Allen, 2008) e ainda pode ter alguma influência sobre os níveis de inteligência (Tang et al., 2007). A atenção plena ou o exercício do mindfulness pode ainda ajudar o sujeito e diminuir a sua reatividade emocional, a alcançar uma melhor forma de enfrentar os problemas e a atingir um estado único de calma e alerta que só é possível mediante esta prática regular. Assim, é de realçar que a facilitação da gestão de emoções relacionadas com a sexualidade, surge da própria experiência e, por isso, é preponderante aprender a acalmar a mente e a desenvolver um estado de consciência plena em cada momento (Franco, Manas \& Justo, 2009).

As competências de aceitação e de consciência de si próprio traduzem, nas técnicas terapêuticas de aceitação (Farmer \& Chapman, 2007), um exercício de atenção constante ao momento presente com o intuito de identificar pensamentos, sentimentos e estados corporais (Paiva, 2009). Isto é justificado pelo facto da ansiedade, do medo e do evitamento interferirem de forma bastante significativa, comprometendo severamente a funcionalidade quotidiana da pessoa em múltiplas áreas, nomeadamente, na vida escolar e/ou profissional, nas rotinas sociais, relacionamentos interpessoais, entre outros (Bados, 2009; D’el Rey \& Pacini, 2006). Assim, pretende-se inverter a forma de funcionamento habitual e substituir o processamento de informação ascendente, contornando as memórias, as crenças e as distorções cognitivas (Brown, Ryan, Creswell \& Niemiec, 2008).

Particularmente em relação à sexualidade, o mindfulness parece contribuir de forma positiva para uma melhora significativa no funcionamento sexual e no bem-estar sexual subjetivo, uma vez que ser sexualmente auto-consciente tem consequências positivas sobre o desempenho sexual. Assim, a autoconsciência interfere de forma positiva com a excitação, com o processo de prazer e, por isso ser mais sensível e consciente de forma a adotar uma postura de abertura e aceitação parece promover a sexualidade do casal (McCarthy \& Wald, 2013; Goldmeier, 2013). Neste sentido, o mindfulness tenta focar-se na mente e no corpo, na atenção plena de tudo o que ocorre e, desta forma, esta prática parece oferecer uma abordagem única para melhorar questões relacionadas com a sexualidade (Brotto, Krychman \& Jacobson, 2008).

A existência de qualquer tipo de alteração no funcionamento sexual leva a uma autoestima bastante reduzida, perda de interesse e até mesmo ao afastamento da vida sexual e íntima devido ao 
constrangimento sentido (McCarthy \& Wald, 2013). É de referir que as disfunções sexuais tendem a ser acompanhadas por emoções e pensamentos negativos e catastróficos, assim ao praticar mindfulness de forma regular, o sujeito consegue estar mais focado no presente a cada momento, deixando de lado um pouco as cognições negativas. A capacidade de concentração em pontos determinantes de excitação sexual, com o mínimo de distrações, é essencial para o sucesso desta tentativa de reprogramação e por isso, o mindfulness pode ser um grande contributo (Goldmeier, 2013).

Uma das premissas básicas do mindfulness na área da sexualidade é a aceitação do relaxamento físico e psicológico, com base na resposta sexual. Assim, o foco de atenção não é sobre o desempenho sexual individual, mas sim no desejo sexual, encarando a satisfação sexual como um processo interpessoal. A componente mindfulness enfatiza assim a consciencialização e a aceitação do nível de envolvimento e de resposta ao invés de forçar um resposta sexual ou levar o sujeito a desistir ou a evitar o processo prazeroso que envolve a atividade sexual. Estratégias e técnicas de mindfulness convidam o Homem a aceitar e adotar um novo conjunto de habilidades físicas e psicológicas, assumindo o total controlo e responsabilidade acerca do seu bem-estar sexual (McCarthy \& Wald, 2013).

No decorrer do referido, o mindfulness associado à sexualidade é utilizado para aumentar o desejo, o prazer, o erotismo e a satisfação sexual do casal ou do indivíduo como ser idiossincrático que é (McCarthy \& Wald, 2013). Tendo em conta que os principais componentes da sexualidade saudável do casal são o desejo e a satisfação, pressupõe-se que a plena consciência reforça o seu desejo sexual e a sua satisfação (McCarthy \& Wald, 2013; Lucena \& Abdo, 2013). Assim, a prática de mindfulness leva a um aumento da capacidade de entender a perspetiva de um parceiro (Carson, Carson, Gil \& Baucom, 2004; Brotto \& Heiman, 2007; Burpee \& Langer, 2005), isto é, ser consciente da opinião do parceiro o que, consequentemente é associada de forma significativa a uma maior satisfação conjugal, melhorando assim o funcionamento sexual e o bem-estar sexual subjetivo (Lazaridou \& Kalogianni, 2013; McCreary \& Alderson, 2013).

Neste sentido, foi definido um modelo causal do processo de atenção durante o funcionamento sexual e, de acordo com alguns autores, os deficits no funcionamento sexual devido à dificuldade de excitação, são causados essencialmente pela incapacidade do sujeito estar atento no momento e não ser capaz de captar corretamente os sinais eróticos que são necessários para a excitação (Lucena \& Abdo, 2013). Masters e Johnson uns anos antes já defendiam o mindfulness nos seus programas de focalização de sensações e, por isso, o foco sensorial é, de facto, a atenção plena no corpo, onde ambos os parceiros devem concentrar-se nas sensações corporais e afastar pensamentos perturbadores. É então sugerida que a prática da atenção plena ajuda os parceiros a aceitar as dificuldades ou mudanças no funcionamento sexual, uma vez que é sugerido que comecem o ato 
sexual sem quaisquer ideias pré-concebidas do que vão sentir, reorientando o pensamento para o não-julgamento e para a aceitação e concentração no momento presente (Goldmeier, 2013).

Desde há muito tempo as tradições filosóficas fazem uso de técnicas de meditação e enfatizam a importância da qualidade da consciência na manutenção e promoção do bem-estar (Brown \& Ryan, 2003). Neste sentido, a atenção plena tem sido alvo de estudos das tradições budistas e desempenha um papel crucial na teoria psicológica, bem como na prática mediativa (Ospina, et al., 2007). Apesar do aumento significativo de pesquisas e debates públicos acerca de aspetos relacionados com problemas e disfunções sexuais (Blanker et al., 2001; Braun et al., 2000; Feldman, Goldstein, Hatzichristou, Krane, \& McKinlay, 1994; Laumann et al., 2005; Laumann, Paik, \& Rosen, 1999; Moreira, Abdo, Torres, Lobo, \& Fittipaldi, 2001; Nicolosi et al., 2004; Nicolosi, Moreira, Shirai, Bin Mohd Tambi, \& Glasser, 2003) pouco se sabe acerca do que realmente constitui a saúde sexual e o seu consequente bem-estar sexual subjetivo.

É certo que, para as mudanças no funcionamento sexual, existem diversas formas de tratamento, nomeadamente farmacológico, no entanto, esta solução não aborda atitudes, crenças, comportamentos, emoções, preocupações, valores, ou seja, elementos psicológicos que têm influência sobre a sua sexualidade. Neste sentido, o mindfulness tenta focar-se na mente e no corpo, na atenção plena de tudo o que ocorre e, desta forma, oferece uma abordagem única para melhorar questões relacionadas com a sexualidade (Brotto, Krychman \& Jacobson, 2008).

De facto, não há um consenso acerca das causas das disfunções ou mudanças no funcionamento sexual das mulheres, todavia, após a prática de mndfulness, os sujeitos descrevem que sentem o corpo separado dos sentimentos e da experiência de prazer, o que, consequentemente, acarreta alterações na resposta fisiológica do próprio corpo (Brotto, 2013). Assim, a atenção plena objetiva o cultivo da consciência ativa do corpo, culminando numa aceitação sem-julgamento o que, consequentemente, aumenta a regulação da atenção, a consciência corporal, a regulação emocional e as mudanças na perspetiva do próprio self (Holzel et al., 2011).

Quando se trata de alterações no funcionamento sexual, estas trazem, geralmente, pensamentos negativos, angústia, julgamentos negativos e, por isso, o mindfulness parece ser uma forma efetiva de alterar o foco de atenção das memórias negativas ou do stresse associado ao ato sexual e parece ajudar a focar a atenção nas sensações que ocorrem no momento presente. Na prática de mindfulness aprende-se essencialmente que as sensações corporais, os pensamentos e os sentimentos são eventos da vida temporários que surgem e passam com o tempo (Brotto, 2013).

Para Langer, o mindfulness pressupõe um compromisso com o meio ambiente e inclui um grau elevado de complexidade, flexibilidade de pensamento e ainda uma capacidade para ter em conta diversas perspetivas. Os praticantes de mindfulness tornam-se mais abertos a novas ideias e, 
concomitantemente, desenvolvem a capacidade de concentração e aprendizagem com vista a um aumento da presença e da consciência situacional (Lazaridou \& Kalogianni, 2013).

As evidências apontam que a prática de mindfulness pode ajudar a promover a criatividade e o bemestar, reduzir a ansiedade e ajudar a controlar elevados níveis de ansiedade, sendo que os seus efeitos levam a uma menor reatividade nos relacionamentos, maior liberdade e segurança para os praticantes e para os que estão numa relação com estes e um maior entendimento acerca da natureza das ligações existentes entre as pessoas. Neste sentido, os praticantes de mindfulness são mais conscientes e, por isso, surgem sentimentos e comportamentos mais informados e produtivos uma vez que conseguem entender melhor os pontos de vista dos outros e isto, também se aplica à sexualidade. 0 referido é congruente com o facto de uma das principais razões para os distúrbios sexuais ser a incapacidade dos sujeitos para se concentrarem nos estímulos de excitação e, pelo referido, é sugerido que a prática de mindfulness auxilia o indivíduo a focar-se no momento presente, algo fulcral para o bom funcionamento sexual e prazer. Neste sendo, os praticantes de mindfulness tendem a ter uma vida e um funcionamento sexual mais satisfatório (Lazaridou \& Kalogianni, 2013).

$\mathrm{Na}$ grande maioria das terapias sexuais, não são consideradas algumas questões tais como cognitivas, emocionais e/ou situacionais que podem também influenciar a deteriozação de uma relação e influenciar o bem-estar sexual (Botto, Krychman \& Jacobson, 2008). Assim, a prática de mindfulness torna-se relevante na medida em que se foca mais nos relacionamentos e nas emoções dos indivíduos do que nos sintomas físicos. Neste sentido, esta prática intervém de forma holística conectando o corpo e a mente melhorando significativamente fatores intrapsíquicos que diminuem a satisfação sexual (McCreary \& Alderson, 2013). Melhora ainda o controlo sobre a atenção (Carmody, 2009), permitindo que os sujeitos se autoavaliem e se afastem de pensamentos perturbadores ou angustiantes e dirijam a sua atenção, de forma excluiva, para a experiência sexual (McCreary \& Alderson, 2013).

Neste seguimento, as diversas alterações que advém da prática de mindfulness têm consequências benéficas diretas sobre a vida sexual dos casais, bem como na sua intimidade e ligação. Com a prática regular de mindfulness, a vida sexual do casal é reforçada no sentido em que é possível ser experimentada a intimidade emocional mais profunda entre os parceiros durante o ato sexual o que, consequentemente, intensifica a experiência física e de prazer. 0 referido justifica-se pelo facto dos sujeitos terem menos estímulos distratores e de se conseguirem concentrar melhor no presente, intensificando deste modo a resposta sexual e focando a sua atenção única e exclusivamente na experiência (McCreary \& Alderson, 2013).

No decorrer do referido e indo de encontro com algumas pesquisas, o mindfulness parece aumentar de forma significativa a resposta sexual, a satisfação sexual, o desejo sexual e a lubrificação sexual 
(Baker \& Absenger, 2013; Brotto, Krychman \& Jacobson, 2008). Assim e tendo em consideração que a perceção dos estímulos e das respostas fisiológicas tem implicações no tratamento de disfunções sexuais (Jong, 2009), o mindfulness acarreta benefícios promissores na abordagem do desejo sexual e em mudanças no funcionamento sexual, para além de melhorar as avaliações subjetivas de bemestar sexual subjetivo (Brotto, Basson \& Luria, 2008). Neste sentido, a atenção é essencialmente a tomada de posse pela mente, de forma clara, acerca dos objetos do pensamento (James, 1890) o que se traduz na orientação de estímulos sensoriais, na ativação de ideias da memória e na manutenção de um estado de alerta focado no momento presente (Spiering \& Everaerd, 2007; Posner, 1994).

Assim sendo, a literatura realça de forma bastante repetida a atenção que deve ser dada às disfunções ou alterações no funcionamento sexual (Coleman, 2003) e, por isso, é defendido que a cognição é responsável ou pelo menos tem impacto sobre a facilitação ou o impedimento das fases de resposta sexual o que, consequentemente, acarreta alterações também no bem-estar sexual subjetivo. Neste sentido, é sugerido que o mindfulness pode ser treino benéfico, uma vez que este treina a atenção dirigida do sujeito, podendo melhorar a resposta sexual (Jong, 2009). Este, por seu turno, ainda fornece às pessoas um senso de significados e de propósitos para lidar com eventos adversos da vida (Halstead \& Fernsler 1993; Burkhardt, 1994; Dombeck, 1995 cit in Coleman, 2003), treinando a mente e levando a uma melhoria na função e satisfação sexual, tanto em pessoas com mudanças no funcionamento sexual, como em pessoas que não têm qualquer patologia associada (Jong, 2009).

Em suma, é de referir que, assemelhando-se a um número infindável de teorias, o mindfulness, na sexualidade, representa uma responsabilidade pessoal por si mesmo, sobre o desejo, prazer e função sexual. Não obstante, cada parceiro desempenha um papel crucial no processo de mindfulness e por isso, o ideal é que ambos, isto é, o casal, pratique esta terapia com o intuito de se verificarem melhores significativas na experiência sexual do casal (McCarthy \& Wald, 2013). Neste sentido, o mindfulness aumenta a abertura para o outro, a clareza na perceção da relação e ainda o grau de proximidade emocional o que se traduz num melhor funcionamento sexual e, consequente, bem-estar sexual subjetivo (Brown \& Ryan, 2003). 


\section{Referências Bibliográficas}

Abdo, C. (2008).Uma análise crítica do Manual Diagnóstico e Estatístico de Distúrbios Mentais para a disfunção sexual. Diagn Tratamento, 13 (4), 189-91;

American Psychiatric Association (2013). Manual de diagnóstico e estatística das perturbações mentais ( $5^{\mathrm{a}}$ ed.). Lisboa: Climepsi;

Amishi, P. Krompinger, J. \& Baime, M. (2007) Mindfulness training modifies subsystems of attention. Cognitive, Affective, \& Behavioral Neuroscience, 7 (2), 109-119;

Anderson, N. D., Lau, M. A., Segal, Z. V. \& Bishop, S. R. (2007). Mindfulness-Based Stress Reduction and Attentional Control. Clinical Psychology \& Psychotherapy, 14, 449-463;

Arch, J. J., \& Craske, M. G. (2006). Mechanisms of mindfulness: Emotion regulation following a focused breathing induction. Behavior Research and Therapy, 44, 1849-1858;

Atanes, A., Barros, V., Ronzani, T., Leonelli, L., Kozasa, E., Andreoni, S. \& Demarzo, M. (2012). Validade e confiabilidade da "Escala de Atenção Plena e Consciência" (MAAS) e "Questionário das Cinco Facetas de Mindfulness" (FFMQ) entre profissionais da Atenção Primária à Saúde. Journal of Family and Community Medicine;

Bados, A. (2009). Fobia social. Universitat de Barcelona, Facultat de Psicologia;

Baer, R. (2003). Mindfulness Training as a Clinical Intervention: A conceptual and empirical review. American Psychological Association, 10 (2), 125-143;

Baer, R. A., Smith, G. T., Hopkins, J., Krietemeyer, J., \& Toney, L. (2006). Using Self-Report Assessment Methods to Explore Facets of Mindfulness. Assessment, 13 (1), 27-45M

Baer, R., Smith, G., Hopkins, J., Krietemeyer, J., \& Toney, L. (2006). Using Self-Report Assessment Methods to Explore Facets of Mindfulness. Assessment, 13 (1), 27-45;

Baer, R., Smith, G., Lykins, E., Button, D., Krietemeyer, J., Sauer, S., \& Walsh, E. (2008). Construct Validity of the Five Facet Mindfulness Questionnaire in Meditating and Nonmeditating Samples. Assessment, 15, 329-342;

Baer, R. A. (2003). Mindfulness Training as a Clinical Intervention: A Conceptual and Empirical Review. Clin Psychol Sci Prac, 10, 125-143; 
Baer, R. A., Smith, G., Hopkins, J., Krietemeyer, J. \& Toney, L. (2006). Using Self-Report Assessment Methods to Explore Facets of Mindfulness. Assessment, 13 (1), 27-45;

Baker, A. \& Absenger, W. (2013). Sexual Wellness Enhancement and Enrichment Training (SWEET): A hypothetical group model for addressing sexual health and wellbeing. Sexual and Relationship Therapy, 28 (1/2), 48-62;

Balon, R. (2008) In Pursuit of (Sexual) Happiness and Well-Being: A Response. Journal of Sex \& Marital Therapy, 34, 298-301;

Barker, M. (2010). Reflections: Towards a mindful sexual and relationship therapy. Sexual and Relationship Therapy, 28 (1/2), 148-152;

Bishop, S. (2002). What do We Really Know About Mindfulness-based Stress Reduction? Psychosomatic Medicine, 64, 71-84;

Bishop, S. R., Lau, M., Shapiro, S., Carlson, L., Anderson, N. D., Carmody, J., Segal, Z. V., Abbey, S., Speca, M., Velting, D., \& Devins, G. (2004). Mindfulness: A proposed operational definition. Clinical Psychology: Science and Practice, 11 (3), 230-241;

Blanker, M. H., Bosch, J. L. H. R., Groeneveld, F. P. M. J., Bohnen, A. M., Prins, A. \& Thomas, S. (2001). Erectile and ejaculatory dysfunction in a community-based sample of men 50-78 years old: Prevalence, concern, and relation to sexual activity. Urology, 57, 763-768;

Borynski, M. (2006). Clarifying the Construct of Mindfulness and its Relationship to Neuroticism. Dissertation - Faculty of the College of Graduate Studies of Central Michigan University: Michigan;

Braun, M., Wassmer, G., Klotz, T., Reifenrath, B., Mathers, M., \& Engelmann, U. (2000). Epidemiology of erectile dysfunction: Results of the "Cologne Male Survey". International Journal of Impotence Research, 12, 305-311;

Brefczynski-Lewis, J. A., Lutz, A., Schaefer, H. S., Levinson, D. B., Davidson, R. J. (2007) Neural correlates of attencional expertise in long-term meditation practitioners. Proceedings of the National Academy of Sciences, 104 (27),11483-11488;

Broderick, P. C. (2005). Mindfulness and coping with dysphoric mood: Contrasts with rumination and distraction. Cognitive Therapy and Research, 29 (5), 501-510.;

Brotto, L. \& Heiman, J. (2007). Mindfulness in sex Therapy: Applications for women with sexual difficulties following gynecologic cancer. Sexual and Relationship Therapy, 22 (1); 
Brotto, L. (2013), Mindful Sex. Canadian Journal of Human Sexuality, 22 (2), 63-68;

Brotto, L. A., Basson, R., \& Luria, M. (2008). A mindfulness-based group psychoeducational intervention targeting sexual arousal disorder in women. Journal of Sexual Medicine, 5 (7), 16461659;

Brotto, L. A., Krychman, M., \& Jacobson, P. (2008). Eastern approaches for enhancing women's sexuality: Mindfulness, acupuncture, and yoga. Journal of Sexual Medicine, 5, 2741-2748;

Brotto, L.A., \& Heiman, J.R. (2007). Mindfulness in sex therapy: Applications for women with sexual difficulties following gynaecologic cancer. Sexual and Relationship Therapy, 22 (1), 3-11;

Brown, K. W., Ryan, R. M., \& Creswell, J. D. (2007). Mindfulness: Theoretical foundations and evidence for its salutary effects. Psychological Inquiry, 18 (3), 211-237;

Brown, K. W., Ryan, R. M., Creswell, J. D., \& Niemiec, C. P. (2008). Beyond me: Mindful responses to social threat. In H. A. Wayment, e J. J. Bauer, Transcending Self-Interest: Psychological Explorations of the Quiet Ego (pp. 75-84);

Brown, K., \& Ryan, R. (2003). The Benefits of Being Present: mindfulness and its role in psychological well-being. Journal of Personality and Social Psychology, 84 (4), 822-848;

Brown, K.W. \& Kasser, T. (2005). Are Psychological and Ecological Well-Being Compatible? The Role of Values, Mindfulness, and Lifestyle. Social Indicators Research, 74, 349 - 368;

Brown, K.W. \& Ryan, R.M. (2003). The Benefits of Being Present: Mindfulness and Its Role in Psychological Well-Being. Journal of Personality and Social Psychology, 84 (4), 822-848;

Buchheld, N., Grossman, P., \& Walach, H. (2001). Measuring mindfulness in insight meditation (vipassana) and meditation-based psychotherapy: The development of the Freiburg Mindfulness Inventory (FMI). Journal for Meditation and Meditation Research, 1, 11-34;

Buckstegge, K., Gouveia, M., Mafra, M. \& Bobato, S. (2009). Disfunções sexuais femininas: um estudo exploratório com um psicólogo que atua em âmbito clínico. Centro Científico Conhecer Enciplopédia Biosfera, 5 (8);

Burkhardt M. (1994) Becoming and connecting elements of spirituality for women. Holistic Nursing Practice 4, 12-21;

Burpee, L. C. \& Langer, E. J. (2005). Mindfulness and marital satisfaction. Journal of Adult Development, 12, 43 - 51; 
Cardaiotto, L. A. (2005). Assessing Midfulness: The development of a bidimensional measure o awareness and acceptance. Tese de Doutoramento apresentada à Faculty of Drexel University;

Carson, J. W., Carson, K. M., Gil, K. M., \& Baucom, D. H. (2004). Mindfulness-based relationship enhancement. Behavior Therapy, 35, 471-494;

Cayoun, B. A. (2006). Mindfulness-based Cognitive Behaviour Therapy: General Principles and Guidelines Tasmania: Uniprint, University of Tasmania;

Cebolla A. y Miró, M. T. (2007). Eficacia de la terapia cognitiva basada en la atención plena en el tratamiento para la depresión. Revista de Psicoterapia, 17, 133-156;

Chambers, R., Yee Lo, B. C., \& Allen, N. B. (2008). The impact of intensive mindfulness training on attentional control, cognitive style, and affect. Cognitive Therapy and Research, 32, 303-322;

Coffey, K. A. \& Hartman, M. (2008). Mechanisms of Action in the Inverse Relationship Between Mindfulness and Psychological Distress. Complementary Health Practice Review, 13 (2), 79-91;

Coleman, C. (2003). Spirituality and sexual orientation: Relationship to mental well-being and functional health status. Issues and inovations in nursing practice - Department of Integrative Systems, School of Nursing, Virginia Commonwealth University, Richmond, Virginia, USA;

Collumbien M, Busza J, Cleland J, Campbell O. Social (2012). Science methods for research on sexual and reproductive health. Geneva: Who;

Crooks, R. \& Baur, K. (2008). Our sexuality. Belmont, CA: Wadsworth;

Davison, S., Bell, R., LaChina, M., Holden, S., \& Davis, S. (2009). The relationship between selfreported sexual satisfaction and general well-being in women. Journal of Sexual Medicine, 6, 26902697;

Dennerstein, L., Dudley, E. \& Burger, H. (2001). Are changes in sexual functioning during midlife due to aging or menopause. Fertility and Sterility, 76 (3);

Derryberry, D., \& Reed, M. (2002). Anxiety-related attentional biases and their regulation by attentional control. Journal of Abnormal Psychology, 111, 225-236;

Diamond, L. \& Huebner, D. (2012) Is Good Sex Good for you? Rethinking Sexuality and Health. Social and Personality Psychology Compass, 6, 54-69; 
Dimidjian, S., \& Linehan, M. (2003). Defining an agenda for future research on the clinical application of Mindfulness practice. Clinical Psychology: Science and Practice, 10, 166-171;

Edwards, R. T. \& Bryning, L. (2013). Measuring the cost effectiveness of mindfulness - challenges and opportunities. Paper presented at the International Scientific Conference 2013, Mindfulness in Society Conference;

Edwards, R., Bryning, L. \& Crane, R. (2014) Design of Economic Evaluations of Mindfulness-Based Interventions: Tem Methodological Questions of which to be Mindful. Mindfulness, 6 (3), 490-500;

Eysenck, M. W., Derakshan, N., Santos, R., \& Calvo, M. G. (2007). Anxiety and cognitive performance: Attentional control theory. Emotion, 7, 336-353;

Farmer, R. F., \& Chapman, A. L. (2007). Behavioral interventions in cognitive behavior therapy: Practical guidance for putting theory into action (pp. 251-278). American Psychological Association: Washington, DC;

Feldman, G., Hayes, A., Kumar, S., Greeson, J., \& Laurenceau, J. (2007). Mindfulness and emotion regulation: The development and initial validation of the Cognitive and Affective Mindfulness ScaleRevised (CAMS-R). Journal of Psychopathology and Behavioral Assessment, 29 (3), 177-190.

Feldman, H. A., Goldstein, I., Hatzichristou, D. G., Krane, R. J., \& McKinlay, J. B. (1994). Impotence and its medical and psychosocial correlates: Results of the Massachusetts Male Aging Study. Journal of Urology, 151, 54-61;

Fernandes, M. (2010). Atenção Plena e Ansiedade do desempenho em músicos. Tese para obtenção do grau Mestre em Psicologia Clínica e da Saúde. Portugal: Universidade do Algarve;

Fletcher, L., \& Hayes, S. (2005). Relational Frame Theory, Acceptance and Commitment Therapy, and a Functional Analytic Definition of Mindfulness. Journal of Rational-Emotive \& CognitiveBehavior Therapy, 23 (4), 315-336;

Franco, C., Mañas, I. \& Justo, I., (2009). Reducción de los niveles de estrés, ansiedad y depresión en docentes de educación especial através de un programa de mindfulness. Revista Educación Inclusiva, 2 (3), 11-22;

Fresco, D. M., Moore, M. T., van Dulmen, M., Segal, Z. V., Teasdale, J. D., Ma, H. (2007). Initial psychometric properties of the Experiences Questionnaire: Validation of a self-report measure of decentering. Behavior Therapy, 38, 234-236; 
Frohlich, P., \& Meston, C. (2002). Sexual functioning and selfreported depressive symptoms among college women. Journal of Sex Research, 39, 321-325;

Fugl-Meyer, A., \& Fugl-Meyer, K. (2002). Sexual disabilities are not singularities. International Journal of Impotence Research, 14, 487-493;

Gable, S. L., \& La Guardia, J. G. (2007). Positive processes in close relationships across time, partners, and context: A multilevel approach. In Ong, A. D. \& Van-Dulmen, M. H. M. (2008). Oxford Handbook of Methods in Positive Psychology (pp. 576-590). New York: Oxford University Press;

Gable, S. L., Reis, H. T., Impett, E. A., \& Asher, E. R. (2004). What do you do when things go right? The intrapersonal and interpersonal benefits of sharing positive events. Journal of Personality \& Social Psychology, 87, 228-245;

Gardner, F.L., \& Moore, Z.E. (2004). A Mindfulness-Acceptance-Commitment-Based Approach to Athletic Performance Enhancement: Theorical considerations. Behavior Therapy, 35 (4), 707 - 723 ;

Garland, E.L. (2007). The Meaning of Mindfulness: A Second-Order Cybernetics of Stress, Metacognition, and Coping. Complementary Health Practice Review, 12 (1), 15-30;

Germer, C. (2005). Mindfulness: what is it? What does it matter? In Germer, C., Siegel, R., \& Fulton, P. (2013) Mindfulness and Psychotherapy, (pp.3-27). New York, NY: Guilford Press;

Goldmeier, D. (2013). Mindfulness: A sexual medicine physician's personal and professional journey. Sexual and Relationship Therapy, 8 (1/2);

Gottman, J. M., \& Levenson, R. W. (2000). The timing of divorce: Predicting when a couple will divorce over a14-year period. Journal of Marriage \& the Family, 62, 737-745;

Greeson, J. M. (2009). Mindfulness Research Update. Complementary Health Practice Review., 14 (1), 10-18;

Gregório, S, \& Gouveia, J. (2011) Facetas do Mindfulness: Caraterísticas psicométricas de um instrumento de avaliação. Avaliação psicológica em Comtexto Clínico, 54, 259-280;

Gregório, S. \& Pinto-Gouveia, J. (2013) Mindful Attention and Awareness: Relationships with Psychopathology and Emotion Regulation. Spanish Journal of Psychology, 16 (79), 1-10;

Grossman, P. (2010). Mindfulness for psychologists: Paying kind attention to the perceptible. Mindfulness, 1, 87-97; 
Gunarantana, H. (1992). Mindfulness in plain English. Boston: Wisdom Publications;

Halstead M. \& Fernsler J. (1993) Coping strategies of long-term cancer survivors. Cancer Nursing, 2, 94-100;

Hanh, N. T. (1976). The miracle of mindfulness: A manual for meditation. Boston: Beacon;

Hanh, T. N. (1999). The heart of the Buddha's teaching. New York: Broadway;

Hayes, S. (2004). Acceptance and Commitment Therapy and the New Behavior Therapies. In S. Hayes \& V. Follette \& M. Linehan (Eds.), Mindfulness and Acceptance: Expanding the CognitiveBehavioral Tradition, 1-29;

Hayes, S. C., Strosahl, K. D. \& Wilson, K. G. (1999). Acceptance and commitment therapy : na experiential approach to behavior change. New York: Guilford Press;

Hayes, S., \& Wilson, K. (2003). Mindfulness: Method and process. Clinical Psychology: Science and Practice, 10, 161-165;

Hayes, S. C. \& Gregg, J. (2002). Functional contextualism and the self. Selfrelations in the psychotherapy process, 391-307;

Holas, P. \& Jankowski, T. (2013). A cognitive perspective on mindfulness. International Journal of Psychology, 48 (3), 232-243;

Holmberg, D., Blair, K., \& Phillips, M. (2010). Women's sexual satisfaction as a predictor of wellbeing in same-sex versus mixed-sex relationships. Journal of Sex Research, 47, 1-11;

Holzel, B. K., Lazar, S. W., Gard, T., Schuman-Olivier, Z., Vago, D. R. \& Ott, U. (2011). How does mindfulness meditation work? Proposing mechanisms of action from a conceptual and neural perspective. Perspectives on Psychological Science, 6 (6), 537-559;

Hooghe, M. (2012) In Sexual Well-Being Parto of Subjective Well-Being? Na Empirical Analysis of Belgian (Flemish) Survey Data Using na Extended Well-Being Scale. Journal of sex research, 49, 264273;

Ivanovski, B. \& Malhi, G. S. (2007). The Psychological and Neurophysiological Concomitants of Mindfulness Forms of Meditation. Acta Neuropsychiatrica 19 (2), 76-91;

James, W. (1890). The principles of psychology. New York: Holt; 
Jha, A. P., Krompinger, J. \& Baime, M. (2007). Mindfulness training modifies subsystems of attention. Cognitive, Affective \& Behavioral Neuroscience, 7 (2), 109-119;

Jong, D. (2009) The role of attention in sexual arousal: Implications for treatment of sexual dysfunction. Journal of sex research, 46 (2-3), 237-248;

Justo, C., Manãs, I. \& Martínez, E. (2010). Mejora en algunas dimensiones de salud percebida en pacientes com fibromialgia mediante la aplicación de un -programa de meditación mindfulness. Psychology, Society \& Education, 2 (2), 117-130;

Kabat-Zinn, J. (1982). An Outpatient Program in Behavioral Medicine for Chronic Pain Patients Based on the Practice of Mindfulness Meditation: Theoretical Considerations and Preliminary Results. Gen Hosp Psychiatry, 4 (1), 33-47;

Kabat-Zinn, J. (1990). Full Catastrophe Living: Using the Wisdom of Your Body and Mind to Face Stress, Pain, and Illness. New York: Delacorte;

Kabat-Zinn, J. (2003). Mindfulness-based intervention in context: Past, present, and future. Clinical Psychology, Science and Practice, 10 (2), 144-156;

Kabat-Zinn, J., Lipworth, L. \& Burney, R. (1985). The Clinical Use of Mindfulness Meditation for the Self-Regulation of Chronic Pain. Journal of Behavioral Medicine, 8 (2), 163-190;

Keller, A. McGarvey, E. \& Clayton, A. (2006). Reliability and Construct Validity of the Changes in Sexual Functioning Questionnaire Short-Form (CSFQ-14), Journal of Sex \& Marital Therapy, 32, 4352 ;

Langer, E. J. (1989). Mindfulness. Cambridge, Mass: Perseus Books;

Langer, E. J. (1992). Matters of mind: Mindfulness/mindlessness in perspective. Consciousness and Cognition, 1, 289-305;

Lau, M., Bishop, S., Segal, Z., Buis, T., Anderson, N., Carlson, L., Shapiro, S. \& Carmody, J. (2006). The Toronto Mindfulness Scale: Development and validation. Journal of Clinical Psychology, 62, 1445-1467;

Laumann, E. O., Nicolosi, A., Glasser, D. B., Paik, A., Gingell, C. \& Moreira, E. (2005). Sexual problems among women and men aged 40-80 years: Prevalence and correlates identified in the Global Study of Sexual Attitudes and Behaviors. International Journal of Impotence Research, 17, 39-57; 
Laumann, E. O., Paik, A. \& Rosen, R. C. (1999). Sexual dysfunction in the United States: Prevalence and predictors. Journal of the American Medical Association, 281 (6), 537-544;

Lazar, S., Kerr, C. E., Wasserman, R. H., Gray, J. R., Greve, D., Treadway, M. T., et al. (2005). Meditation experience is associated with increased cortical thickness. NeuroReport, 16, 1893-1897;

Lazaridou, A. \& Kalogianni, C. (2013). Mindfulness and Sexuality. Sexual and Relationship Therapy, 28 (1/2), 29-38;

Leary, M. R., Adams, C. E. \& Tate, E. B. (2006). Hypoegoic self-regulation: Exercising self-control by diminishing the influence of the self. Journal of Personality, 74, 1803-1831;

León, B. (2008). Atención plena y rendimiento académico en estudiantes de enseñanza secundaria. European Journal of Education and Psychology, 1 (3), 17-26;

Linehan, M. (1993). Cognitive-behavioral treatment of borderline personality disorder. New York: Guilford Press;

Linehan, M. M. (1987). Dialectical behavior therapy for borderline personality disorder: Theory and method. Journal of the Menninger Clinic, 51, 261-276;

Lucena, B. \& Abdo, C. (2013) O papel da ansiedade na (dis)função sexual Programa de Estudos em Sexualidade (ProSex) do Instituto de Psiquiatria do Hospital das Clínicas da Faculdade de Medicina da Universidade de São Paulo. Diagn Tratamento, 18 (2), 94-98;

Marlatt, G. A. \& Kristeller, J. L. (1999). Mindfulness and meditation. In W. R. Miller (Ed.), Integrating spirituality into treatment: Resources for practitioners (pp. 67-84). Washington, DC: American Psychological Association;

Masters, W. H. \& Johnson, V. E. (1966) Human sexual response. New York: Bantam Books;

McCarthy, B. \& Wald, L. (2013) Mindfulness and Good Enough Sex. Sexual and Relationship Therapy. American University, Washington, USA;

McCarthy, B., \& McCarthy, E. (2003). Rekindling desire. New York, NY: Routledge;

McCraty, R., Atkinson, M., Lipsenthal, L. \& Arguelles, L. (2003). Impact of the Power to Change Performance Program on Stress and Health Risks in Correctional Officers. HeartMath Research Center, Institute of HeartMath; 
McCreary, S. \& Alderson, K. (2013). The Perceived effects of practising meditation on women's sexual and relational lives. Sexual and Relationship Therapy, 28 (1/2), 105-119;

Mendonça, C., Silva, T., Arrudai, J., García-Zapata, M. \& Amaral, W. (2012) Função Sexual Feminina - Aspetos normais e patológicos, prevalência no Brasil, diagnóstico e tratamento. Feminina, 4 (4);

Moreira, E. D. Jr., Abdo, C. H. N., Torres, E. B., Lobo, C. F. L. \& Fittipaldi, J. A. S. (2001). Prevalence and correlates of erectile dysfunction: Results of the Brazilian Study of Sexual Behaviour. Urology, 58, 583-588;

Namto, S. (1989). Atención Plena Momento a Momento - Meditación Vipassana. México: Yug;

Nanamoli, B., \& Bodhi, B. (1995). The middle length discourses of the Buddha: The majjhima nikaya. Boston: Wisdom Publications;

Neff, K. D. (2003). Self-compassion: An alternative conceptualization of a healthy attitude toward oneself. Self and Identity, 2, 85-102;

Neves, C. (2011). A relação entre Mindfulness, Auto-Compaixão, Vergonha e Psicopatologia em praticantes e não praticantes de Meditação/Yoga. Dissertação Apresentada ao ISMT para obtenção do Grau de Mestre em Psicologia Clínica. Coimbra: Instituto Superior Miguel Torga;

Nicolosi, A., Laumann, E. O., Glasser, D. B., Moreira, E., Paik, A. \& Gingell, C. (2004). Sexual behavior and sexual dysfunctions after age 40: The Global Study of Sexual Attitudes and Behaviors. Urology, 64, 991-997;

Nicolosi, A., Moreira, E. D., Shirai, M., Bin Mohd Tambi, M. I., \& Glasser, D. B. (2003). Epidemiology of erectile dysfunction in four countries: Cross-national study of the prevalence and correlates of erectile dysfunction. Urology, 61, 201-206;

Nussbaum, M. \& Sen, A. (1993). The quality of life. Oxford: Clarendon;

Oberg, K., Fugl-Meyer, K., \& Fugl-Meyer, A. (2002). On sexual well-being in sexually abused Swedish women: Epidemiological aspects. Sexual and Relationship Therapy, 17, 329-341;

Organização Mundial de Saúde (1993). Classificação de Transtornos Mentais e de Comportamento da CID-10: Descrições Clínicas e Diretrizes Diagnósticas. Porto Alegre: Artmed;

Ospina, M. B., Bond, T. K., Karkhaneh, M., Tjosvold, L., Vandermeer, B., Liang, Y., Bialy, L., Hooton, N., Buscemi, N., Dryden, D. M., \& Klassen, T. P. (2007). Meditation Practices for Health: State of the Research. Evidence Report/Technology Assessment, 155; 
Pagnoni, G., \& Cekic, M. (2007). Age Effects on Gray Matter Volume and Attentional Performance in Zen Meditation. Neurobiology of Aging, 28 (10), 1623 - 1627;

Pais-Ribeiro, J. L. P. (2002). O consentimento informado na investigação em psicologia da saúde é necessário?. Psicologia, saúde e Doença, 3 (1), 11-22;

Paiva, M. (2009) Ansiedade a exames no contexto do ensino secundário: o papel da ansiedade social, auto-criticismo e competências de mindfulness e aceitação. Instituto Superior Miguel Torga. Portugal: Coimbra

Posner, M. I. (1994). Attention: The mechanisms of consciousness. Proceedings of the National Academy of Sciences of the United States of America, 91, 7398-7403;

Ramos, N., Hernández, S. M. \& Blanca, M. (2009). Efecto de un programa integrado de Mindfulness e Inteligencia Emocional sobre la estrategias cognitivas de regulación emocional. Ansiedad y Estrés, 15 (2/3), 207-216;

Roemer, L. \& Borkovec, T. D. (1994). Effects of suppressing thoughts about emotional material. Journal of Abnormal Psychology, 103, 467-474;

Rosen, R. \& Bachmann, G. (2008) Sexual well-being, hapiness and satisfaction in women: The case for a new conceptual paradigma. Journal of Sex \& Marital Therapy, 34, 291-297;

Rothwell, N. (2006). The Different Facets of Mindfulness. Journal of Rational-Emotive \& CognitiveBehavior Therapy, 24 (1), 79-86;

Satcher, D. (2001). The Surgeon General's Call to Action to Promote Sexual Health and Responsible Sexual Behavior. Washington, DC: Department of Health and Human Services;

Schwartz, J., \& Begley, S. (2002). The mind and the brain: Neuroplasticity and the power of mental force. New York: HarperCollins;

Segal, Z. V., Williams, J. M. G., \& Teasdale, J. D. (2002). Mindfulness-based cognitive therapy for depression: A new approach to preventing relapse. New York: Guilford Press;

Shapiro, S. L., Carlson, L. E., Astin, J. A. \& Freedman, B. (2006). Mechanisms of mindfulness. Journal of Clinical Psychology, 62, 373-386.;

Shapiro, S. \& Schwartz, G. E. (2005). The role of intention in self-regulation: Toward intentional systemic mindfulness. In Boekaerts, M., Pintrich P. R. \& Zeidner M. (2004). Handbook of selfregulation (pp. 253-273). San Diego: Academic Press; 
Shapiro, S. L., Carlson, L. E., Astin, J. A., \& Freedman, B. (2006). Mechanisms of Mindfulness. Journal of Clinical Psychology, 62 (3), 373-386;

Siegel, R. D., Germer, C. K. \& Olendzki, A. (2009), «Mindfulness: What Is It? Where Did It Come From?», In Didonna, F. (20010) Clinical Handbook of Mindfulness, New York: Springer;

Sillifant, B. (2007). A Conceptual Basis for the Refinement of an Operational Definition of Mindfulness. Massey University: New Zealand;

Simón, V. (2001). El ego, la conciencia, y las emociones: un modelo interactivo. Psicothema, 13 (2), 205-213;

Simón, V. (2011) Aprender a Practicar Mindfulness y abrir el corazón a la sabiduría y la compasión. Barcelona: Sello;

Singh, N., Lancioni, G., Wahler, R., Winton, A., \& Singh, J. (2008). Mindfulness Approaches in Cognitive Behavior Therapy. Behavioural and Cognitive Psychotherapy, 36, 659-666;

Solursh, D. S., Ernst, J. L., Lewis, R. W., Prisant, M., Mills, T. M., Solursh, L. P. \& Salazar, W. H. (2003). The human sexuality education of physicians in North American medical schools. International Journal of Impotence Research, 15 (5), 41-45;

Sternberg, R. J. (2000). Images of mindfulness. Journal of Social Science, 56 (1), 11-26;

Tang, Y., Ma, Y., Wang, J., Fan, Y., Feng, S., Lu, Q., Yu, Q., Sui, D., Rothbart, M. K., Fan, M. \& Posner, M. I. (2007). Short-term meditation training improves attention and self-regulation. Proceedings of the National Academy of Sciences, 104 (43), 17152-17156;

Teasdale, J. D., Segal, Z. V., \& Williams, M. G. (1995). How does cognitive therapy prevent depressive relapse and why should attentional control (mindfulness training) help? Behaviour Research and Therapy, 33, 25-39;

Thera, N. (1962). The heart of Buddhist meditation. New York: Weiser;

Traeen, B. \& Schaller, S. (2010) Subjective Sexual Well-Being in a Web Sample of Heterosexual Norwegians. International Journal of Sexual Health, 22, 180-194;

Vandenberghe, L. \& Assunção, A. (2009) Concepções de mindfulness em Langer e Kabat-Zinn: Um encontro da ciência ocidental com a espiritualidade oriental. Contextos Clínicos, 2 (2), 124-135; 
Varela, F. J., Thompson, E. \& Roach, E. (1991). The embodied mind: Cognitive science and human experience. Cambridge: MIT Press;

Vitiello, N. \& Conceição, I. S. C. (1993). Manifestações da Sexualidade nas Diferentes Fases da Vida. Revista Brasileira de Sexualidade Humana, 4 (1), 47-59;

Walach, H., Buchheld, N., Buttenmuller, V., Kleinknecht, N., \& Schmidt, S. (2006). Measuring mindfulness - the Freiburg Mindfulness Inventory (FMI). Personality and Individual Differences, 40, 1543-1555;

Walsh, R. (1980). The consciousness disciplines and the behavioral sciences:Questions of comparison and assessment. American Journal of Psychiatry, 137, 663-673;

Weinstein, N., Brown, K. W. \& Ryan, R. M. (2009). A Multi-Method Examination of the Effects of Mindfulness on Stress Attribution, Coping, and Emotional Well-Being. Journal of Research in Personality, 43, 374-385;

Zettle, R. \& Hayes, S. C. (1986). Dysfunctional control by client verbal behavior: The context of reason giving. The Analysis of Verbal Behavior, 4, 30-38. 
Anexo 2: Comprovativo da
submissão à revista do
artigo científico 